Edith Cowan University

Research Online

Research outputs 2014 to 2021

2016

Equiaxed Ti-based composites with high strength and large plasticity prepared by sintering and crystallizing amorphous powder

Lehua Liu

Chao Yang

L. M. Kang

Yan Long

Zhiyu Xiao

See next page for additional authors

Follow this and additional works at: https://ro.ecu.edu.au/ecuworkspost2013

Part of the Materials Science and Engineering Commons

10.1016/j.msea.2015.10.048

This is an Author's Accepted Manuscript of:

Liu, L. H., Yang, C., Kang, L. M., Long, Y., Xiao, Z. Y., Li, P. J., \& Zhang, L. C. (2016). Equiaxed Ti-based composites with high strength and large plasticity prepared by sintering and crystallizing amorphous powder. Materials Science and Engineering: $A, 650,171-182$.

https://doi.org/10.1016/j.msea.2015.10.048

This Journal Article is posted at Research Online.

https://ro.ecu.edu.au/ecuworkspost2013/1066 


\section{Authors}

Lehua Liu, Chao Yang, L. M. Kang, Yan Long, Zhiyu Xiao, Peijie Li, and Laichang Zhang

This journal article is available at Research Online: https://ro.ecu.edu.au/ecuworkspost2013/1066 


\section{Author's Accepted Manuscript}

Equiaxed Ti-based composites with high strength and large plasticity prepared by sintering and crystallizing amorphous powder

L.H. Liu, C. Yang, L.M. Kang, Y. Long, Z.Y. Xiao, P.J. Li, L.C. Zhang

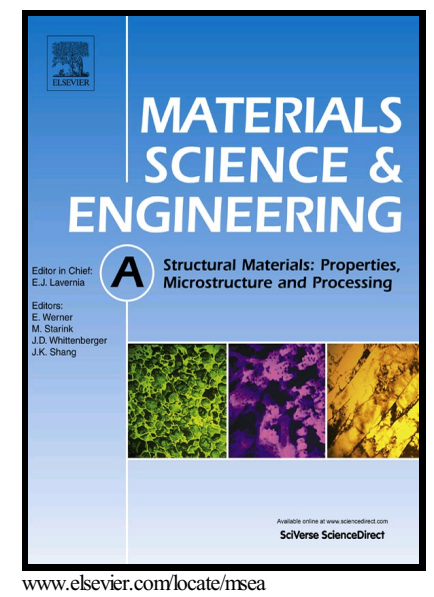

PII: $\quad$ S0921-5093(15)30505-0

DOI: $\quad$ http://dx.doi.org/10.1016/j.msea.2015.10.048

Reference: MSA32899

To appear in: $\quad$ Materials Science \& Engineering $A$

Received date: 8 July 2015

Revised date: 6 October 2015

Accepted date: 12 October 2015

Cite this article as: L.H. Liu, C. Yang, L.M. Kang, Y. Long, Z.Y. Xiao, P.J. Li and L.C. Zhang, Equiaxed Ti-based composites with high strength and largr plasticity prepared by sintering and crystallizing amorphous powder, Material Science \& Engineering A, http://dx.doi.org/10.1016/j.msea.2015.10.048

This is a PDF file of an unedited manuscript that has been accepted fo publication. As a service to our customers we are providing this early version o the manuscript. The manuscript will undergo copyediting, typesetting, an review of the resulting galley proof before it is published in its final citable form Please note that during the production process errors may be discovered whic could affect the content, and all legal disclaimers that apply to the journal pertain 


\title{
Equiaxed Ti-based composites with high strength and large plasticity prepared by sintering and crystallizing amorphous powder
}

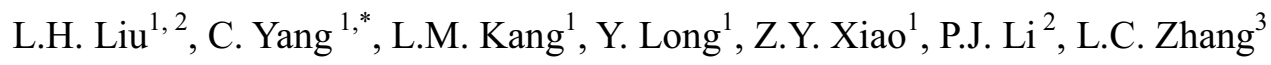 \\ ${ }^{1}$ National Engineering Research Center of Near-net-shape Forming for Metallic Materials,
} South China University of Technology, Guangzhou 510640, China

${ }^{2}$ Department of Mechanical Engineering, Tsinghua University, Beijing 100084, China

${ }^{3}$ School of Engineering, Edith Cowan University, 270 Joondalup Drive, Joondalup, Perth, WA 6027, Australia

\begin{abstract}
:
High-performance titanium alloys with an equiaxed composite microstructure were achieved by sintering and crystallizing amorphous powder. By introducing a second phase in a $\beta$-Ti matrix, series of optimized Ti-Nb-Fe-Co-Al and Ti-Nb-Cu-Ni-Al composites, which have a microstructure composed of ultrafine-grained and equiaxed $\mathrm{CoTi}_{2}$ or $(\mathrm{Cu}, \mathrm{Ni}) \mathrm{Ti}_{2}$ precipitated phases surrounded by a ductile $\beta$-Ti matrix, were fabricated by sintering and crystallizing mechanically alloyed amorphous powder. The as-fabricated composites exhibit ultra-high ultimate compressive strength of $2585 \mathrm{MPa}$ and extremely large compressive plastic strain of around $40 \%$, which are greater than the corresponding ones for most titanium alloys. In contrast, the alloy fabricated by sintering and crystallizing Ti-Zr-Cu-Ni-Al amorphous powder, which possesses significantly higher glass forming ability in comparison with the Ti-Nb-Fe-Co-Al and Ti-Nb-Cu-Ni-Al alloy systems, exhibits a complex microstructure with several intermetallic compounds and a typical brittle fracture feature. The deformation behavior and fracture mechanism indicate that the ultrahigh compressive strength and large plasticity of the as-fabricated equiaxed composites is induced by dislocations pinning effect of the $\mathrm{CoTi}_{2}$ or $(\mathrm{Cu}, \mathrm{Ni}) \mathrm{Ti}_{2}$ second phases and the interaction and
\end{abstract}


multiplication of generated shear bands in the ductile $\beta$-Ti matrix, respectively. The results obtained provide basis guidelines for designing and fabricating titanium alloys with excellent mechanical properties by powder metallurgy.

Keywords: Titanium alloys; powder metallurgy; amorphous alloy; mechanical properties; equiaxed microstructure

Corresponding author, Email: cyang@scut.edu.cn; Tel \& Fax: +86-20-87112111

\section{Introduction}

Titanium alloys have been widely used in many fields due to their high specific strength, excellent corrosion resistance and good biocompatibility [1]. As an important type of structural materials, pursuing higher strength and plasticity in titanium alloys has become the primary goal for researchers to meet the stringent requirements for new engineering applications. To achieve enhanced properties, a series of advanced Ti-based alloys such as bulk metallic glasses and nanostructured materials [2,3] have been fabricated by new fabrication facilities and innovative process routes. However, these alloys usually fail at room temperature in an apparently brittle pattern by forming a single shear band under stress. Furthermore, although strategies of introducing some ductile dispersed micrometer-sized crystalline phases into a glassy matrix or nanostructured matrix have been successfully developed to improve their plasticity $[4,5]$, the small critical size of those alloys cannot meet the requirements for engineering applications. Therefore, it is a big challenge for applications of these advanced materials.

In recent years, a process of sintering and crystallizing amorphous powder has been employed to fabricate larger-scale advanced titanium alloys with high strength and large plasticity $[6,7]$. In this process, amorphous powder was used as precursors to fabricate a high-performance titanium alloy, which was primarily ascribed to the following reasons. Firstly, amorphous powder possesses a special physical property of viscous flow in supercooled liquid region $[8,9]$, which can be used to synthesize the fully or near fully dense 
bulk alloys at relatively low sintering temperatures. Secondly, nanosized or ultrafine grains can easily be achieved by accelerating nucleation rate and suppressing the growth rate of grains induced by increasing heating rate and decreasing sintering temperature during crystallization of amorphous powder [10]. Finally, an equiaxed microstructure is prone to form by sintering and crystallizing of amorphous powder [6]. However, based on the previous results with bulk metallic glasses, the mechanical properties would be drastically deteriorated when crystalline phases such as an intermetallic or complex compounds form in the alloy [11]. Fortunately, it was recognized in previous work that some equiaxed composite alloys fabricated by sintering and crystallizing amorphous powders have exhibited even higher strength and larger plasticity than the corresponding alloys prepared by rapid solidification [6, 12]. Therefore, a question arises about what kind of composition of metallic amorphous powder is most suitable for the process of sintering and crystallizing amorphous powder.

In this work, to understand how chemical constituents of alloys affect the microstructure and mechanical properties of the sintered and crystallized (SCed) alloys, amorphous powder with different compositions was designed and selected to shed light on the general rule for fabricating equiaxed titanium alloys with high mechanical properties using the powder metallurgy process. It is expected that the results obtained in this work can provide some guidelines for designing and fabricating titanium alloys by sintering and crystallizing amorphous powder.

\section{Experimental}

The designed alloys used in this work are listed in Table 1. The chemical compositions are formulated as Ti-Nb-(M-N)-(Al), where $(\mathrm{M}, \mathrm{N})$ are elements $(\mathrm{Fe}, \mathrm{Co})$ or $(\mathrm{Cu}, \mathrm{Ni})$. For comparison purpose, Alloy $\mathrm{A}\left(\mathrm{Ti}_{70} \mathrm{Nb}_{30}\right)$ with single $\beta$-Ti phase and alloy $\mathrm{H}$ $\left(\mathrm{Ti}_{40.6} \mathrm{Zr}_{9.4} \mathrm{Cu}_{37.5} \mathrm{Ni}_{9.4} \mathrm{Al}_{3.1}\right)$, which is a bulk metallic glass former [2], were fabricated. Alloy B $\left(\mathrm{Ti}_{65} \mathrm{Nb}_{22.5} \mathrm{Fe}_{6.25} \mathrm{Co}_{6.25}\right)$ was chosen to study the effect of addition of $\mathrm{Fe}$ and $\mathrm{Co}$ on the microstructure and mechanical properties of single $\beta$-Ti phase alloy (i.e. $\mathrm{Ti}_{70} \mathrm{Nb}_{30}$ ). Alloys $\mathrm{C}-\mathrm{E}$ listed in Table 1 were chosen to investigate the effect of changes in Fe and Co contents on the microstructure and mechanical properties of the alloys. The alloys F and G were selected for the effect of $\mathrm{Nb}$ content on the microstructure and mechanical properties in the 
Ti-Nb-Cu-Ni-Al alloy system.

Table 1 The chemical compositions (in wt $\%$ ) of the designed multicomponent Ti-Nb-(M-N)-(Al) alloys. M, $\mathrm{N}$ are $(\mathrm{Fe}, \mathrm{Co})$ or $(\mathrm{Cu}, \mathrm{Ni})$.

\begin{tabular}{lcccccc}
\hline Alloy Composition (at. \%) & $\mathbf{T i}$ & $\mathbf{N b} / \mathbf{Z r}$ & $\mathbf{M}$ & $\mathbf{N}$ & $\mathbf{A l}$ \\
\hline $\mathrm{A}$ & $\mathrm{Ti}_{70} \mathrm{Nb}_{30}$ & 54.59 & 45.41 & - & - & - \\
$\mathrm{B}$ & $\mathrm{Ti}_{65} \mathrm{Nb}_{22.5} \mathrm{Fe}_{6.25} \mathrm{Co}_{6.25}$ & 52.56 & 35.32 & 5.90 & 6.22 & - \\
$\mathrm{C}$ & $\mathrm{Ti}_{66} \mathrm{Nb}_{13} \mathrm{Fe}_{8} \mathrm{Co}_{6.8} \mathrm{Al}_{6.2}$ & 58.70 & 22.44 & 8.33 & 7.45 & 3.15 \\
$\mathrm{D}$ & $\mathrm{Ti}_{66} \mathrm{Nb}_{13} \mathrm{Fe}_{10} \mathrm{Co}_{4.8} \mathrm{Al}_{6.2}$ & 58.77 & 22.47 & 10.39 & 5.26 & 3.11 \\
$\mathrm{E}$ & $\mathrm{Ti}_{66} \mathrm{Nb}_{13} \mathrm{Fe}_{12} \mathrm{Co}_{2.8} \mathrm{Al}_{6.2}$ & 58.84 & 22.49 & 12.48 & 3.07 & 3.08 \\
$\mathrm{~F}$ & $\mathrm{Ti}_{66} \mathrm{Nb}_{13} \mathrm{Cu}_{8} \mathrm{Ni}_{6.8} \mathrm{Al}_{6.2}$ & 58.06 & 22.19 & 9.34 & 7.34 & 3.07 \\
$\mathrm{G}$ & $\mathrm{Ti}_{71.6} \mathrm{Nb}_{15.8} \mathrm{Cu}_{4.8} \mathrm{Ni}_{4} \mathrm{Al}_{3.8}$ & 61.89 & 26.51 & 5.51 & 4.24 & 1.85 \\
$\mathrm{H}$ & $\mathrm{Ti}_{40.6} \mathrm{Zr}_{9.4} \mathrm{Cu}_{37.5} \mathrm{Ni}_{9.4} \mathrm{Al}_{3.1}$ & 33.40 & 14.74 & 40.96 & 9.48 & 1.40 \\
\hline
\end{tabular}

In the process of sintering and crystallizing amorphous powder, amorphous powder was first prepared from its respective elemental powder by mechanical alloying in a high-energy planetary ball mill (QM-2SP20, apparatus factory of Nanjing University) under a purified argon gas atmosphere $(99.999 \%, 0.5 \mathrm{MPa})$. The diameters of the stainless steel balls were 15, 10 , and $6 \mathrm{~mm}$ with a weight ratio of 1:3:1 respectively. The ball-to-powder mass ratio was approximately 8:1. Approximately $3 \mathrm{~g}$ powder was removed from the mill for X-ray diffraction (XRD) examination (D/MAX-2500/PC; Rigaku Corp., Tokyo, Japan) and differential scanning calorimetry (DSC, Netzsch STA 409 C) at $20^{\circ} \mathrm{C} / \mathrm{min}$ until the formation of fully or near fully glassy phase in all alloys except for alloy A. Subsequently, the as-milled amorphous powder was SCed by heating to different sintering temperatures, such as $900{ }^{\circ} \mathrm{C}$, $950{ }^{\circ} \mathrm{C}$ and $1000{ }^{\circ} \mathrm{C}$ at $100^{\circ} \mathrm{C} / \mathrm{min}$, under an argon atmosphere by a Dr. Sintering SPS-825 system. All SCed bulk alloys had a cylindrical shape with a dimension of $30 \mathrm{~mm}$ in diameter and $10 \mathrm{~mm}$ long.

The phase constitutions and microstructure of the SCed bulk alloys were characterized by X-Ray Diffraction (XRD), scanning electron microscope (SEM) and transmission electron microscope (TEM), respectively. From the XRD results, the lattice parameter $\left(a_{0}\right)$ of the $\beta$-Ti 
phase was determined using a suitable extrapolation of the variation in the lattice parameter as a function of the Nelson-Riley parameter $\left(\cos ^{2} \theta / \sin \theta+\cos ^{2} \theta / \theta\right)$. A Philips XL-30 FEG scanning electron microscope (SEM; Amsterdam, The Netherlands) and a Tecnai G2 F30 field emission gun transmission electron microscope (TEM; FEI, Eindhoven, The Netherlands) coupled with energy dispersive X-ray (EDX) analysis were used for microstructure/fractographic investigation. To evaluate the mechanical properties of the SCed bulk alloys for comparison with the reference alloys, cylindrical specimens of $3 \mathrm{~mm}$ in diameter and $6 \mathrm{~mm}$ in length were tested in a universal testing machine (MTS testing system) under quasistatic loading at a strain rate of $5 \times 10^{-4} \mathrm{~s}^{-1}$, and a small strain gauge was used to calibrate and measure the strain during loading. All the data of mechanical properties were averaged from three mechanical tests.

\section{Results}

\subsection{Preparation of amorphous powder}

Fig. 1(a) displays the XRD patterns of the as-milled alloy powder with different compositions for different milling time. Apparently, for alloys $\mathrm{Ti}_{70} \mathrm{Nb}_{30}$ (alloy $\mathrm{A}$ ), $\mathrm{Ti}_{65} \mathrm{Nb}_{22.5} \mathrm{Fe}_{6.25} \mathrm{Co}_{6.25}$ (alloy B) and $\mathrm{Ti}_{66} \mathrm{Nb}_{13} \mathrm{Fe}_{8} \mathrm{Co}_{6.8} \mathrm{Al}_{6.2}$ (alloy $\mathrm{C}$ ), the milling time for the alloy powder to form amorphous structure decreases with increasing the number of alloying component. The milling time for alloy $\mathrm{C}$ is approximately $70 \mathrm{~h}$ to form nano-sized $\beta$-Ti surrounded by glassy matrix, which has been confirmed by TEM [7]. In contrast, it is difficult for the $\mathrm{Ti}_{70} \mathrm{Nb}_{30}$ (alloy A) to form an amorphous state even after milling for $105 \mathrm{~h}$. The XRD patterns indicate that the as-milled alloy A powder only consists of single $\beta$-Ti phase with a grain size of $10 \mathrm{~nm}$. It can also be found that $\mathrm{Ti}_{40.6} \mathrm{Zr}_{9.4} \mathrm{Cu}_{37.5} \mathrm{Ni}_{9.4} \mathrm{Al}_{3.1}$ (alloy $\mathrm{H}$ ), which can form bulk metallic glass by rapid solidification, reaches a fully amorphous structure only after $20 \mathrm{~h}$ of milling. The difference in the milling time for forming amorphous structure primarily results from the different glass forming ability between different compositions. The $\mathrm{Ti}_{40.6} \mathrm{Zr}_{9.4} \mathrm{Cu}_{37.5} \mathrm{Ni}_{9.4} \mathrm{Al}_{3.1}$ (alloy $\mathrm{H}$ ) is a bulk glass former which can be form fully amorphous phase but $\mathrm{Ti}_{70} \mathrm{Nb}_{30}$ (alloy $\mathrm{A}$ ) is more difficult to form fully amorphous phase by rapid solidification. For alloys $\mathrm{B}$ and $\mathrm{C}$, it is difficult to form bulk metallic glass by rapid 
solidification, but an amorphous phase can form in these alloys by provided energy increase from mechanical alloying [13]. Therefore, alloy $\mathrm{H}$ has significantly larger glass forming ability compared with the alloys A-C. As such, the milling time for alloy $\mathrm{H}$ to form an amorphous structure is far shorter than those for alloys A-C. Fig. 1(b) shows the evolution of the lattice parameter of $\beta$-Ti phase with increasing the milling time. During mechanical alloying, the $\beta$-Ti stabilizer element $\mathrm{Nb}$ dissolves in Ti to form a body-centered cubic (bcc) $\beta$-Ti solid solution. As the atomic radii of Fe, Co and Al elements $(0.135 \mathrm{~nm}, 0.126 \mathrm{~nm}$ and $0.125 \mathrm{~nm}$, respectively) are much smaller than those of $\mathrm{Ti}(0.200 \mathrm{~nm})$ and $\mathrm{Nb}(0.145 \mathrm{~nm})$, the lattice parameter of $\beta$-Ti phase decreases with increasing the milling time due to dissolution of elements $\mathrm{Fe}$ and $\mathrm{Co}$ in $\beta$-Ti phase in the process of milling.

Fig. 2 displays the SEM micrographs of the 70h-milled alloy powder with different compositions. As shown in Fig. 2(a), the particle sizes of the as-milled alloy A powder are of 500-700 $\mu \mathrm{m}$, which are much larger than those of the as-milled $\mathrm{Ti}_{66} \mathrm{Nb}_{13} \mathrm{Cu}_{8} \mathrm{Ni}_{6.8} \mathrm{Al}_{6.2}$ alloy (alloy F) powder reported in Refs [14-15]. The size of the alloy powder does not decrease with increasing the milling time up to $105 \mathrm{~h}$ (not shown here). The alloys B and C powder shows a near spherical morphology with a size of approximately $30 \mu \mathrm{m}$ and $15 \mu \mathrm{m}$ (Figs. 2(b) and (c)), respectively. The size of alloy $H$ powder is about $20-40 \mu \mathrm{m}$. The reasons for the smaller sizes of the alloys B and C powder compared to that of alloy A can primarily be ascribed to the physical properties of different powder. It is well known that milling is a process to refine powders by repeated welding, fracturing and rewelding of powder particles in a high-energy ball mill. For alloy $\mathrm{A}$, the formed bcc $\beta$-Ti phase solid solution is ductile and difficult to break, which make the particle size stable. In contrast, for alloys B and C, more dissolution of elements $\mathrm{Fe}, \mathrm{Co}$ and/or $\mathrm{Al}$ into the $\beta$-Ti phase with increasing the milling time makes the alloy powder brittle to be easily broken along with the effect of the solution strengthening. Therefore, the alloys B and C powder have smaller particle sizes.

\subsection{Microstructure of SCed bulk alloys}

Fig. 3 shows the XRD patterns of the SCed bulk alloys with different compositions. It is found that the alloy $\mathrm{A}\left(\mathrm{Ti}_{70} \mathrm{Nb}_{30}\right)$ sintered at different temperatures is composed of only a single $\beta$-Ti phase; for all of the other studied alloys, the sintering temperature does not affect 
the phase constitutions of the SCed alloys. Therefore, only one XRD pattern is shown in this work for each studied alloy. For $\mathrm{Ti}_{65} \mathrm{Nb}_{22.5} \mathrm{Fe}_{6.25} \mathrm{Co}_{6.25}$ (alloy B) and $\mathrm{Ti}_{66} \mathrm{Nb}_{13} \mathrm{Fe}_{8} \mathrm{Co}_{6.8} \mathrm{Al}_{6.2}$ (alloy $\mathrm{C}$ ) with addition of increasing the contents of $\mathrm{Fe}, \mathrm{Co}$ and $\mathrm{Al}$ in $\mathrm{Ti}_{70} \mathrm{Nb}_{30}$ (alloy A), the alloys begin to precipitate $\mathrm{CoTi}_{2}$ phases along with the $\beta$-Ti phase. An increase in the relative content of Fe does not change the phase constitutions of $\mathrm{Ti}_{66} \mathrm{Nb}_{13} \mathrm{Fe}_{10} \mathrm{Co}_{4.8} \mathrm{Al}_{6.2}$ (alloy D) and $\mathrm{Ti}_{66} \mathrm{Nb}_{13} \mathrm{Fe}_{12} \mathrm{Co}_{2.8} \mathrm{Al}_{6.2}$ (alloy E), i.e. the $\mathrm{CoTi}_{2}$ and $\beta$-Ti phases. In the Ti-Nb-Cu-Ni-Al alloy system, the alloys mainly consist of $\beta$-Ti and $(\mathrm{Cu}, \mathrm{Ni}) \mathrm{Ti}_{2}$ phases for $\mathrm{Ti}_{66} \mathrm{Nb}_{13} \mathrm{Cu}_{8} \mathrm{Ni}_{6.8} \mathrm{Al}_{6.2}$ (alloy $\mathrm{F}$ ). With increasing the $\mathrm{Nb}$ content, $\mathrm{AlNbTi}_{2}$ phase begins to form in the $\mathrm{Ti}_{71.6} \mathrm{Nb}_{15.8} \mathrm{Cu}_{4.8} \mathrm{Ni}_{4} \mathrm{Al}_{3.8}$ (alloy G). For the $\mathrm{Ti}_{40.6} \mathrm{Zr}_{9.4} \mathrm{Cu}_{37.5} \mathrm{Ni}_{9.4} \mathrm{Al}_{3.1}$ (alloy H), the SCed bulk alloy is composed of several intermetallic compounds, such as $\mathrm{CuTi}$, NiTi and $\mathrm{Zr}_{2} \mathrm{Ti}$ phase, and so on. The lattice parameters of the bcc $\beta$-Ti phase in the SCed bulk alloys are summarized in Table 2. It can be found that the lattice parameters of the $\beta$-Ti phase for the SCed alloys are greater than the corresponding ones for their as-milled alloy powder. This is because of the dissolved elements in the amorphous powder, including $\mathrm{Fe}$ and $\mathrm{Co}$, which begin to form a precipitated phase, such as $\mathrm{CoTi}_{2}$. Thus, the lattice parameter of the $\beta$-Ti phases increases with the precipitation of a second phase because the atomic radii of Fe and Co are much smaller than that of Ti.

Fig. 4 shows the microstructure of the SCed bulk alloys by heating to $900{ }^{\circ} \mathrm{C}$ at $100^{\circ} \mathrm{C} / \mathrm{min}$ and holding for $10 \mathrm{~min}$. As seen from the figure, the microstructure of $\mathrm{Ti}_{70} \mathrm{Nb}_{30}$ (alloy A) is mainly composed of a single bcc $\beta$-Ti phase (Fig. 4(a)). The $\mathrm{Ti}_{66} \mathrm{Nb}_{13} \mathrm{Fe}_{8} \mathrm{Co}_{6.8} \mathrm{Al}_{6.2}$ (alloy C) displays a microstructure consisting of equiaxed $\mathrm{CoTi}_{2}$ phases with a size of approximately 200-1000 nm embedded in $\beta$-Ti matrix (Fig. 4(b)). When enhancing the sintering temperature up to $1000{ }^{\circ} \mathrm{C}$, the scale of $\mathrm{CoTi}_{2}$ in the sample increases to approximately $2 \mu \mathrm{m}$ (not shown here). By changing the relative content of Fe and Co, the sizes of $\mathrm{CoTi}_{2}$ phase region in alloys $\mathrm{D}\left(\mathrm{Ti}_{66} \mathrm{Nb}_{13} \mathrm{Fe}_{10} \mathrm{Co}_{4.8} \mathrm{Al}_{6.2}\right)$ and $\mathrm{E}\left(\mathrm{Ti}_{66} \mathrm{Nb}_{13} \mathrm{Fe}_{10} \mathrm{Co}_{4.8} \mathrm{Al}_{6.2}\right)$ decrease with increasing the $\mathrm{Fe}$ content. The size of $\mathrm{CoTi}_{2}$ phase in alloy $\mathrm{E}$ $\left(\mathrm{Ti}_{66} \mathrm{Nb}_{13} \mathrm{Fe}_{10} \mathrm{Co}_{4.8} \mathrm{Al}_{6.2}\right)$ sintered at $900{ }^{\circ} \mathrm{C}$ is approximately $350 \mathrm{~nm}$ (Fig. 4(c)), which is only about one fourth of that in C-900 $\left(\mathrm{Ti}_{66} \mathrm{Nb}_{13} \mathrm{Fe}_{8} \mathrm{Co}_{6.8} \mathrm{Al}_{6.2}\right)$. For alloy $\mathrm{F}\left(\mathrm{Ti}_{66} \mathrm{Nb}_{13} \mathrm{Cu}_{8} \mathrm{Ni}_{6.8} \mathrm{Al}_{6.2}\right)$ in the Ti-Nb-Cu-Ni-Al system, sample F-900 shows a microstructure composed of equiaxed $(\mathrm{Cu}, \mathrm{Ni}) \mathrm{Ti}_{2}$ regions dispersed in $\beta$-Ti matrix, and the scale of these two regions is $200-450 \mathrm{~nm}$ 
(Fig. 4d). For the alloy with a higher $\mathrm{Nb}$ content, alloy G-900 $\left(\mathrm{Ti}_{71.6} \mathrm{Nb}_{15.8} \mathrm{Cu}_{4.8} \mathrm{Ni}_{4} \mathrm{Al}_{3.8}\right)$ displays a microstructure consisting of equiaxed $(\mathrm{Cu}, \mathrm{Ni}) \mathrm{Ti}_{2}$ and $\mathrm{AlNbTi}_{2}$ phases embedded in a $\beta$-Ti matrix (Fig. 4(e)). It can be found that the alloys prepared by sintering and crystallizing amorphous powder have completely different microstructure (i.e. equiaxed phases dispersed in ultrafine-grained or nano-sized matrix) from the nanostructure-dendrite bimodal microstructure (i.e. micron-sized ductile dendrites embedded in ultrafine-grained or nano-sized eutectic matrix) in the melt-solidified alloy with analogous compositions $[3,12,16,17]$. During the process routes investigated (i.e. sintering and crystallizing amorphous powder), the sintering amorphous powder typically undergoes nucleation and growth, which is similar in the solidification. It is known that, compared with solidification process, the diffusion coefficient of each element in powder during the process of sintering and crystallizing is far smaller than that in melt. However, the amorphous powder in this work was sintered at a high heating rate of $100{ }^{\circ} \mathrm{C} / \mathrm{min}$ by spark plasma sintering. Such a high heating rate can promote nucleation and suppress grain growth $[10,18]$. Hence, it is difficult to form a dendritic phase in the process of sintering and crystallizing amorphous powder. Fig. 4(f) presents the microstructure of alloy $\mathrm{H}\left(\mathrm{Ti}_{40.6} \mathrm{Zr}_{9.4} \mathrm{Cu}_{37.5} \mathrm{Ni}_{9.4} \mathrm{Al}_{3.1}\right)$, showing that the phase distribution in the alloy is cluttered and disorganized. Although the alloy was also consolidated from amorphous powder, this alloy has significantly different phase constituents, morphologies, and distributions from the composite microstructure in the other alloys investigated in this work.

\subsection{Mechanical behavior of SCed bulk alloys}

Fig. 5(a) shows the compressive engineering strain-stress curves for the SCed bulk alloys. The corresponding mechanical properties obtained by averaging three tests are summarized in Table 2. It is evident that, except for the brittle facture behavior observed in alloy $\mathrm{H}$, all the other alloys exhibit an excellent combination of high strength and large plasticity. For alloy A-1000, the single $\beta$-Ti phase alloy shows yield strength of approximately $1200 \mathrm{MPa}$ and a large compressive plasticity at room temperature, indicating that the alloy A with single bcc $\beta$-Ti phase possesses excellent plastic deformation ability. Compared with alloy A, the alloy B with precipitated $\mathrm{CoTi}_{2}$ phase in the matrix has higher 
yield strength and decreased plasticity. For alloys C, D and E, the yield strengths increase with increasing the Fe content, resulting from the grain refinement of both $\mathrm{CoTi}_{2}$ and $\beta-\mathrm{Ti}$ phases in these alloys (Figs. 4(b) and (c)). The $\mathrm{Ti}_{66} \mathrm{Nb}_{13} \mathrm{Fe}_{12} \mathrm{Co}_{2.8} \mathrm{Al}_{6.2}$ alloy (E-900) exhibits a high yield strength of $1892 \mathrm{MPa}$, which is higher than those of most titanium alloys reported so far $[12,19-20]$. For the alloy series "S-X" with the same composition, the yield strength decreases and plastic strain increases with increasing the sintering temperature (Table 2). For example, the yield strength of the samples B-900, B-950 and B-1000 is 1501, 1438 and 1350 $\mathrm{MPa}$, respectively, and their corresponding plastic strain is $36.9 \%, 38.1 \%$ and $38.8 \%$, respectively. This is because of the increase in grain size with increasing sintering temperature. For example, the grain size of sample B-900 is about $500 \mathrm{~nm}$, while the size would increase to about $2 \mu \mathrm{m}$ when the alloy were fabricated at temperature of $1000{ }^{\circ} \mathrm{C}$. For the alloy $\mathrm{F}\left(\mathrm{Ti}_{66} \mathrm{Nb}_{13} \mathrm{Cu}_{8} \mathrm{Ni}_{6.8} \mathrm{Al}_{6.2}\right)$ consolidated from amorphous powder, the yield strength, ultimate strength and plastic strain are $1450 \mathrm{MPa}, 2350 \mathrm{MPa}$, and 28.5\%, respectively. These values are larger than the corresponding ones for the solidified counterparts alloy with a nanostructured matrix surrounding in situ precipitated ductile $\beta$-Ti dendrites [12]. Increasing the $\mathrm{Nb}$ content decreases the yield strength but increase the plasticity of the alloy. Sample G-1000 displays yield strength of $1305 \mathrm{MPa}$, ultimate strength of $2294 \mathrm{MPa}$ and plastic strain of $40.5 \%$. 
Table 2 Summary of the compression testing results and the lattice parameter $a_{0}$ of $\beta$-Ti phase for the sintered and crystallized bulk alloys with different compositions. E: Young's modulus, $\sigma_{y}$ : yield stress, $\sigma_{\max }$ : ultimate compression, $\varepsilon_{p}$ : plastic strain $\varepsilon_{p}$, and $n$ : work-hardening exponent. "S-X" indicates the alloy composition sintered at a specific sintering temperature, where "S" represents the alloy composition and " $X$ " denotes the sintering temperature.

\begin{tabular}{llllllll}
\hline Compositions & Specimen & $\begin{array}{c}\boldsymbol{E} \\
(\mathbf{G P a})\end{array}$ & $\begin{array}{c}\boldsymbol{\sigma}_{\boldsymbol{y}} \\
\mathbf{( M P a )}\end{array}$ & $\begin{array}{c}\boldsymbol{\sigma}_{\text {max }} \\
(\mathbf{M P a})\end{array}$ & $\begin{array}{c}\boldsymbol{\varepsilon}_{\boldsymbol{p}} \\
(\mathbf{\%})\end{array}$ & $\boldsymbol{n}_{\boldsymbol{0}}$ & $\begin{array}{c}\boldsymbol{a}_{\boldsymbol{0}} \\
(\boldsymbol{\AA})\end{array}$ \\
\hline $\mathrm{Ti}_{70} \mathrm{Nb}_{30}$ & $\mathrm{~A}-1000$ & 30.1 & 1250 & 2625 & 50.4 & 0.08 & 3.2903 \\
$\mathrm{Ti}_{65} \mathrm{Nb}_{22.5} \mathrm{Fe}_{6.25} \mathrm{Co}_{6.25}$ & $\mathrm{~B}-900$ & 42.8 & 1501 & 2356 & 36.9 & 0.21 & 3.2623 \\
& $\mathrm{~B}-950$ & 44.2 & 1438 & 2426 & 38.1 & 0.19 & 3.2641 \\
& $\mathrm{~B}-1000$ & 42.1 & 1350 & 2450 & 38.8 & 0.19 & 3.2606 \\
$\mathrm{Ti}_{66} \mathrm{Nb}_{13} \mathrm{Fe}_{8} \mathrm{Co}_{6.8} \mathrm{Al}_{6.2}$ & $\mathrm{C}-900$ & 49.8 & 1591 & 2349 & 26.9 & 0.20 & 3.2497 \\
& $\mathrm{C}-950$ & 48.9 & 1527 & 2516 & 32.1 & 0.21 & 3.2503 \\
& $\mathrm{C}-1000$ & 49.1 & 1475 & 2585 & 34.2 & 0.21 & 3.2511 \\
$\mathrm{Ti}_{66} \mathrm{Nb}_{13} \mathrm{Fe}_{10} \mathrm{Co}_{4.8} \mathrm{Al}_{6.2}$ & $\mathrm{D}-900$ & 54.3 & 1742 & 2154 & 17.5 & 0.19 & 3.2466 \\
& $\mathrm{D}-950$ & 53.2 & 1700 & 2300 & 25.3 & 0.20 & 3.2560 \\
& $\mathrm{D}-1000$ & 54.1 & 1609 & 2362 & 29.2 & 0.19 & 3.2507 \\
$\mathrm{Ti}_{66} \mathrm{Nb}_{13} \mathrm{Fe}_{12} \mathrm{Co}_{2.8} \mathrm{Al}_{6.2}$ & $\mathrm{E}-900$ & 52.6 & 1892 & 2300 & 19.5 & 0.19 & 3.2495 \\
& $\mathrm{E}-950$ & 55.2 & 1705 & 2279 & 21.5 & 0.18 & 3.2569 \\
& $\mathrm{E}-1000$ & 53.2 & 1624 & 2272 & 22.5 & 0.19 & 3.2546 \\
$\mathrm{Ti}_{66} \mathrm{Nb}_{13} \mathrm{Cu}_{8} \mathrm{Ni}_{6.8} \mathrm{Al}_{6.2}$ & $\mathrm{~F}-900$ & 65.0 & 1450 & 2350 & 28.5 & 0.18 & 3.2651 \\
$\mathrm{Ti}_{71.6} \mathrm{Nb}_{15.8} \mathrm{Cu}_{4.8} \mathrm{Ni}_{4} \mathrm{Al}_{3.8}$ & $\mathrm{G}-900$ & 60.1 & 1301 & 2305 & 39.7 & 0.14 & 3.2657 \\
& $\mathrm{G}-950$ & 60.3 & 1312 & 2305 & 41.2 & 0.14 & 3.2654 \\
& $\mathrm{G}-1000$ & 59.2 & 1305 & 2294 & 40.5 & 0.14 & 3.2687 \\
$\mathrm{Ti}_{40.6} \mathrm{Zr}_{9.4} \mathrm{Cu}_{37.5} \mathrm{Ni}_{9.4} \mathrm{Al}_{3.1}$ & $\mathrm{H}-750$ & 60.2 & 800 & - & - & & - \\
& $\mathrm{H}-800$ & 62.3 & 825 & - & - & & - \\
\hline
\end{tabular}

Table 3 summarizes the compressive mechanical properties of representative Ti-based composites with different compositions fabricated by rapid solidification or powder metallurgy. It is found that the alloys, with a composite microstructure composed of equiaxed precipitated phases dispersed in a ductile matrix exhibit improved mechanical properties, which are superior to those for nanostructured Ti-based composites with in situ precipitated ductile $\beta$-Ti dendrites fabricated by rapid solidification. For example, in the Ti-Nb-Fe-Co-Al alloy system, the alloy $\mathrm{Ti}_{66} \mathrm{Nb}_{13} \mathrm{Fe}_{8} \mathrm{Co}_{6.8} \mathrm{Al}_{6.2}$ sintered at $1000{ }^{\circ} \mathrm{C}$ (i.e. C-1000) shows a high ultimate strength of $2585 \mathrm{MPa}$, which is higher than those for $\left(\mathrm{Ti}_{65.5} \mathrm{Fe}_{34.5}\right)_{93} \mathrm{Nb}_{7}(2574 \mathrm{MPa})$ 
[21], $\mathrm{Ti}_{70} \mathrm{Fe}_{15} \mathrm{Co}_{15}(2350 \mathrm{MPa})$ [17] and $\mathrm{Te}_{67} \mathrm{Fe}_{14} \mathrm{Co}_{14} \mathrm{~V}_{5}$ (2040 MPa) [16]. Such a high ultimate strength is also higher than those for most Ti-based bulk metallic glasses [22-24]. The mechanical properties of these alloys reported in this work are also better than those of the fabricated alloys in previous work [6,18,25-26]. The plasticity of $37.8 \%$ for the alloy $\mathrm{Ti}_{71.6} \mathrm{Nb}_{15.8} \mathrm{Cu}_{4.8} \mathrm{Ni}_{4} \mathrm{Al}_{3.8} \quad(\mathrm{G}-1000) \quad$ is larger than those for the rapid-solidified nanostructure-dendrite composites, such as $\mathrm{Ti}_{66.1} \mathrm{Nb}_{13.9} \mathrm{Cu}_{8} \mathrm{Ni}_{4.8} \mathrm{Sn}_{7.2} \quad(\sim 30 \%)$ [27], $\mathrm{Ti}_{64} \mathrm{Ta}_{12.0} \mathrm{Cu}_{11.2} \mathrm{Ni}_{9.6} \mathrm{Sn}_{3.2} \quad(17.9 \%) \quad[20], \quad$ and $\quad \mathrm{Ti}_{60} \mathrm{Nb}_{10} \mathrm{Cu}_{14} \mathrm{Ni}_{12} \mathrm{Sn}_{4} \quad$ (14.5\%) [3], $\mathrm{Ti}_{63.375} \mathrm{Fe}_{34.125} \mathrm{Sn}_{2.5}$ (12.5\%) [28]. However, the SCed alloy $\mathrm{H}$ with a complex and cluttered microstructure is dominated by brittle fracture; the ultimate strength of approximately 800 MPa for the samples at different sintering temperatures is significantly lower than that of the alloy consolidated from amorphous powders with a microstructure of equiaxed second phases dispersed in a ductile matrix.

Fig. 5(b) displays the true stress-strain curves of alloy C-1000 and the single $\beta$-Ti phase A-1000. To evaluate the work-hardening exponent $n, \ln \left(\sigma_{t}\right)$ versus $\ln \left(\varepsilon_{t}\right)$ is also plotted in the Fig. 5(b) inset. For comparison, the exponent $n$ of all other SCed bulk alloys is listed in Table 2. For the present single $\beta$-Ti phase alloy $\mathrm{A}, n$ is about 0.08 . the value of $n$ is about 0.21 for alloy $\mathrm{C}-1000$, which is 2.5 times of that for alloy A. The distinct hardening for the alloys B-G is because of the precipitation of $\mathrm{CoTi}_{2}$ or $(\mathrm{Cu}, \mathrm{Ni}) \mathrm{Ti}_{2}$ phases in the SCed bulk alloys (Figs. $3-5)$. 
Table 3 Summary of the compressive testing data of the representative Ti-based composites with different compositions fabricated by rapid solidification or sintering and crystallizing amorphous powder.

\begin{tabular}{|c|c|c|c|c|c|}
\hline Process & Alloy composition & $\begin{array}{c}\sigma_{y} \\
(\mathbf{M P a})\end{array}$ & $\begin{array}{c}\sigma_{\max } \\
(\mathbf{M P a})\end{array}$ & $\begin{array}{c}\varepsilon_{f} \\
(\%)\end{array}$ & Ref \\
\hline \multirow[t]{13}{*}{ Rapid solidification } & $\mathrm{Ti}_{66.1} \mathrm{Nb}_{13.9} \mathrm{Cu}_{8} \mathrm{Ni}_{4.8} \mathrm{Sn}_{7.2}$ & 1024 & 2000 & 30 & [27] \\
\hline & $\mathrm{Ti}_{64} \mathrm{Ta}_{12.0} \mathrm{Cu}_{11.2} \mathrm{Ni}_{9.6} \mathrm{Sn}_{3.2}$ & 1073 & 2214 & 17.9 & {$[20]$} \\
\hline & $\mathrm{Ti}_{60} \mathrm{Nb}_{10} \mathrm{Cu}_{14} \mathrm{Ni}_{12} \mathrm{Sn}_{4}$ & 1312 & 2401 & 14.5 & {$[3]$} \\
\hline & $\mathrm{Ti}_{60} \mathrm{Ta}_{10} \mathrm{Cu}_{14} \mathrm{Ni}_{12} \mathrm{Sn}_{4}$ & 1568 & 2322 & 0 & {$[3]$} \\
\hline & $\mathrm{Ti}_{66} \mathrm{Nb}_{13} \mathrm{Cu}_{8} \mathrm{Ni}_{6.8} \mathrm{Al}_{6.2}$ & 1195 & 2043 & 30.5 & {$[12]$} \\
\hline & $\left(\mathrm{Ti}_{65.5} \mathrm{Fe}_{34.5}\right)_{93} \mathrm{Nb}_{7}$ & 2182 & 2574 & 12.5 & {$[21]$} \\
\hline & $\mathrm{Ti}_{67.27} \mathrm{Fe}_{27.73} \mathrm{Sn}_{6}$ & 1253 & 2020 & 14 & [29] \\
\hline & $\left(\mathrm{Ti}_{0.72} \mathrm{Fe}_{0.28}\right)_{96} \mathrm{Ta}_{4}$ & 2215 & 2531 & 5.8 & {$[30]$} \\
\hline & $\mathrm{Ti}_{70} \mathrm{Fe}_{15} \mathrm{Co}_{15}$ & 1750 & 2350 & 16.5 & {$[17]$} \\
\hline & $\mathrm{Te}_{67} \mathrm{Fe}_{14} \mathrm{Co}_{14} \mathrm{Sn}_{5}$ & 1460 & 1830 & 24 & {$[16]$} \\
\hline & $\mathrm{Te}_{67} \mathrm{Fe}_{14} \mathrm{Co}_{14} \mathrm{~V}_{5}$ & 1825 & 2040 & 8 & {$[16]$} \\
\hline & $\mathrm{Ti}_{70} \mathrm{Fe}_{17} \mathrm{Co}_{14} \mathrm{Cu}_{6}$ & 1870 & 2100 & 5.6 & {$[16]$} \\
\hline & $\mathrm{Ti}_{69.4} \mathrm{Fe}_{14.8} \mathrm{Co}_{14.8} \mathrm{~B}_{1}$ & 1650 & 1700 & 11 & {$[16]$} \\
\hline \multirow{4}{*}{$\begin{array}{l}\text { Sintering and } \\
\text { crystallizing } \\
\text { amorphous powder } \\
\text { (Previous work) }\end{array}$} & $\mathrm{Ti}_{66} \mathrm{~V}_{13} \mathrm{Cu}_{8} \mathrm{Ni}_{6.8} \mathrm{Al}_{6.2}$ & 1528 & 2118 & 8.6 & {$[31]$} \\
\hline & $\mathrm{Ti}_{66.1} \mathrm{Nb}_{22.4} \mathrm{Zr}_{4} \mathrm{Ta}_{1} \mathrm{Fe}_{6.4}$ & 2258 & 2544 & 8.1 & {$[32]$} \\
\hline & $\mathrm{Ti}_{66} \mathrm{Nb}_{18} \mathrm{Cu}_{6.4} \mathrm{Ni}_{6.1} \mathrm{Al}_{3}$ & 1931 & 2327 & 7.1 & {$[33]$} \\
\hline & $\mathrm{Ti}_{66} \mathrm{Nb}_{13} \mathrm{Cu}_{8} \mathrm{Ni}_{6.8} \mathrm{Al}_{6.2}$ & 1446 & 2415 & 31.8 & {$[6]$} \\
\hline \multirow{5}{*}{$\begin{array}{l}\text { Sintering and } \\
\text { crystallizing } \\
\text { amorphous powder } \\
\text { (This work) }\end{array}$} & $\mathrm{Ti}_{65} \mathrm{Nb}_{22.5} \mathrm{Co}_{6.25} \mathrm{Fe}_{6.25}$ & 1350 & 2450 & 38.8 & (B-1000) \\
\hline & $\mathrm{Ti}_{66} \mathrm{Nb}_{13} \mathrm{Fe}_{8} \mathrm{Co}_{6.8} \mathrm{Al}_{6.2}$ & 1475 & 2585 & 34.2 & $(\mathrm{C}-1000)$ \\
\hline & $\mathrm{Ti}_{66} \mathrm{Nb}_{13} \mathrm{Fe}_{10} \mathrm{Co}_{4.8} \mathrm{Al}_{6.2}$ & 1609 & 2362 & 29.2 & (D-1000) \\
\hline & $\mathrm{Ti}_{66} \mathrm{Nb}_{13} \mathrm{Fe}_{12} \mathrm{Co}_{2.8} \mathrm{Al}_{6.2}$ & 1892 & 2300 & 19.5 & $(\mathrm{E}-900)$ \\
\hline & $\mathrm{Ti}_{71.6} \mathrm{Nb}_{15.8} \mathrm{Cu}_{4.8} \mathrm{Ni}_{4} \mathrm{Al}_{3.8}$ & 1305 & 2294 & 40.5 & $(\mathrm{G}-1000)$ \\
\hline
\end{tabular}

\subsection{Deformed microstructure of SCed bulk alloys}

To reveal the relationships between high strength and large plasticity in these equiaxed-grained composites, the corroded SEM parallelepiped specimens and TEM specimens were selected for investigations regarding the deformation behavior and fracture 
mechanism. Fig. 6(a) shows the TEM bright-field micrograph of the sample B-1000 experienced partial deformation at strain of $20 \%$, presenting a microstructure of ultrafine grained $\mathrm{CoTi}_{2}$ with a size of approximately $700 \mathrm{~nm}$ surrounded by a $\beta$-Ti matrix. This finding is consistent with the SEM observations in Fig. 4(b). The average chemical compositions of the $\beta$-Ti and $\mathrm{CoTi}_{2}$ phases, detected and estimated from the EDX analysis in TEM by averaging six measurements, are $\mathrm{Ti}_{62.9} \mathrm{Nb}_{22.7} \mathrm{Fe}_{2.6} \mathrm{Co}_{0.8}$ and $\mathrm{Ti}_{61.9} \mathrm{Nb}_{2.1} \mathrm{Fe}_{11.8} \mathrm{Co}_{12.1}$, respectively. Apparently, cracks are preferentially formed at the grain boundaries of the $\mathrm{CoTi}_{2}$ and $\beta$-Ti phases (Fig. 6(a)). Distinct dislocations are observed in the $\beta$-Ti matrix whilst they are rarely observed in the $\mathrm{CoTi}_{2}$ phase. The corresponding selected area electron diffraction (SAED) pattern (Fig. 6(b)) of the dislocations in the $\beta$-Ti phase along the $[111]_{\beta-T i}$ zone axis displays elongated diffraction spots along the crystal planes, indicating severe lattice distortions inside the deformed $\beta$-Ti phase. Further high-resolution TEM image of a formed floc is shown in Fig. 6(c); the Fig. 6(c) inset shows a Fourier-transformed image for a square area. To observe the alignment of the (110) crystal plane, an inverse Fourier transformation for flocks-like in the lower bottom side of the square in Fig. 6(c) is shown in Fig. 6(d). Fringe patterns parallel to the (110) plane are observed, and the spacing of the fringes is nearly equal to the (110) inter-planar spacing of the $\beta$-Ti phases. Considerable distortion of the lattice fringes extends over some (110) planes, as arrowed. Therefore, it can also be concluded that the $\beta$-Ti matrix possesses excellent plastic deformation and work-hardening capacity by comparing the TEM images of $\mathrm{CoTi}_{2}$ and $\beta$-Ti phase regions.

Fig. 7 shows the TEM images of the partially deformed (strain at 20\%) alloy G-1000 sample. As shown in Fig. 7(a), the alloy G has a microstructure composed of equiaxed $(\mathrm{Cu}, \mathrm{Ni}) \mathrm{Ti}_{2}$ and $\mathrm{AlNbTi}_{2}$ phases dispersed in a $\beta$-Ti matrix. The grain size of the $(\mathrm{Cu}, \mathrm{Ni}) \mathrm{Ti}_{2}$ and $\mathrm{AlNbTi}_{2}$ phases is near $750 \mathrm{~nm}$ and $600 \mathrm{~nm}$, respectively. A large number of dislocations are also formed in the deformed matrix. Compared with the TEM observations for alloy B-1000 (Fig. 6), few cracks are observed at the grain boundaries of the $(\mathrm{Cu}, \mathrm{Ni}) \mathrm{Ti}_{2}$ or $\mathrm{AlNbTi}_{2}$ phase regions or the $\beta$-Ti phase region, whilst a large number of dislocations are blocked by the $(\mathrm{Cu}, \mathrm{Ni}) \mathrm{Ti}_{2}$ or $\mathrm{AlNbTi}_{2}$ phases (Fig. 7(b)). High-resolution TEM image (Fig. 7(c)) shows 
that shear bands with widths of approximately $7 \mathrm{~nm}$ are formed at the grain boundaries of the $(\mathrm{Cu}, \mathrm{Ni}) \mathrm{Ti}_{2}$ and $\beta-\mathrm{Ti}$ phases, which are likely the origins of the macroscopic cracks. In addition, high-resolution TEM image of the $\mathrm{AlNbTi}_{2}$ phase is also presented in Fig. 7(d) along with the corresponding SAED patterns of the $\beta-\mathrm{Ti},(\mathrm{Cu}, \mathrm{Ni}) \mathrm{Ti}_{2}$ and $\mathrm{AlNbTi}_{2}$ phases (Figs. 7(e)-(g)), which confirm that the $\beta$-Ti and $\mathrm{AlNbTi}_{2}$ phases have a bcc structure and $(\mathrm{Cu}, \mathrm{Ni}) \mathrm{Ti}_{2}$ phase has a face-centered cubic (fcc) structure.

Fig. 8 presents the SEM micrographs of the polished and fractured surfaces of bulk alloy samples. For the fractured specimen A-1000, many shear bands aligning approximately $45^{\circ}$ along the direction of compressive stress are found on the fractured surface. The spacing between the parallel shear bands is approximately 3-5 $\mu \mathrm{m}$ (Fig. 8(a)), indicating that the as-fabricated alloy has excellent plastic deformation ability [4]. For the alloy B-1000 specimen with a microstructure of equiaxed $\mathrm{CoTi}_{2}$ phase surrounded by a ductile $\beta$-Ti matrix, shear bands are mainly observed in the matrix and they are restricted to the $\beta$-Ti regions by the $\mathrm{CoTi}_{2}$ phase. The spacing between the shear bands decreases to approximately $120 \mathrm{~nm}$ (Fig. 8(b)). Cracks are located inside the ultrafine grained $\mathrm{CoTi}_{2}$ phases and at the interfaces between the ultrafine grained $\mathrm{CoTi}_{2}$ phase and $\beta$-Ti matrix. Similar phenomena are also observed in the deformed alloy C-1000 sample. Shear bands and cracks form in the deformed sample, and the spacing between the shear bands is approximately $250 \mathrm{~nm}$ in alloy C-1000 (Fig. 8(c)). However, for the deformed alloy G-1000, although a large number of shear bands are formed in the ductile $\beta$-Ti matrix (Fig. 8(d)), few cracks are observed inside the ultrafine grained $(\mathrm{Cu}, \mathrm{Ni}) \mathrm{Ti}_{2}$ phase regions or at the interfaces between the ultrafine grained $(\mathrm{Cu}, \mathrm{Ni}) \mathrm{Ti}_{2}$ phase and $\beta$-Ti matrix. The deformation behavior observed by SEM (Fig. 8) is in good agreement with the TEM observations (Figs. 6 and 7)

Fig. 9 shows SEM fracture surfaces of the SCed bulk alloys. The fractography of alloy B-950 exhibits a honeycomb-like feature, which corresponds to a large plastic deformation and shows an ultrafine grained microstructure. For B-950, the grain size is approximately 400-600 nm. A crack can be found at the grain boundary of the $\mathrm{CoTi}_{2}$ and $\beta$-Ti phases. The $\beta$-Ti phase seems to have better plastic deformation ability than the $\mathrm{CoTi}_{2}$ phase (Fig. 9(b)). This is consistent with the TEM observations (Fig. 6(a)) and the SEM observations (Fig. 8(b)). The alloy G-900 having a microstructure with $(\mathrm{Cu}, \mathrm{Ni}) \mathrm{Ti}_{2}$ phase dispersed in a $\beta$-Ti matrix displays a fracture morphology with honeycomb-like feature (Fig. 9(d)). But cracks 
are rarely observed at the grain boundaries of the $(\mathrm{Cu}, \mathrm{Ni}) \mathrm{Ti}_{2}$ and $\beta$-Ti phases in $\mathrm{G}-900$. Same scenario is shown in the F-900 (Fig.9(c)).

\section{Discussion}

\subsection{Fracture mechanism of SCed bulk alloys}

As presented above, the as-fabricated alloys by sintering and crystallizing amorphous alloy powder display composite microstructures. Alloys B-G with microstructures of equiaxed second phase surrounded by a ductile $\beta$-Ti matrix exhibit an excellent combination of high strength and large plasticity. In contrast, for the alloy A with single $\beta$-Ti phase, although it has a high plasticity, the yield strength is lower than those for the alloys with equiaxed composite microstructures. Alloy $\mathrm{H}$ with a complex microstructure displays brittle fracture. Thus, the difference in strengths and plasticity of the alloys studied can be explained based on different deformation and facture features. The alloys B-G with equiaxed composite microstructure may undergo a special deformation and fracture behaviors compared to the alloy A with single $\beta$-Ti phase and the alloy $\mathrm{H}$ having complex microstructure.

For the alloys B-G having an equiaxed composite, nanoindentation measurements indicate that the hardness of the $(\mathrm{Cu}, \mathrm{Ni}) \mathrm{Ti}_{2}$ phase regions are approximately $1 / 3$ to $1 / 2$ lower than that of the $\beta$-Ti phase[34]. According to Tabor's relation, hardness value is approximately 3 times the yield strength for metallic materials [35]. It indicates that the $\mathrm{CoTi}_{2}$ or $(\mathrm{Cu}, \mathrm{Ni}) \mathrm{Ti}_{2}$ phases have yield strengths much lower than the $\beta$-Ti phase. However, according to the mechanical properties of alloy A (Tables 2 and 3) and the TEM and SEM observations (Figs. 6, 7(a) and 8), the $\beta$-Ti phases possesses better plastic deformation ability. Under compressive stress, deformation occurs simultaneously in both $\mathrm{CoTi}_{2} /(\mathrm{Cu}, \mathrm{Ni}) \mathrm{Ti}_{2}$ and $\beta$-Ti phase regions, while plastic deformation occurs primarily in the ductile $\beta$-Ti matrix (Fig. 8). With increasing stress, a large number of dislocations are generated in the ductile $\beta$-Ti matrix, which interacted with and are pinned by the ultrafine grained $\mathrm{CoTi}_{2}$ or $(\mathrm{Cu}, \mathrm{Ni}) \mathrm{Ti}_{2}$ phases (Figs. 6 and 7), thus sustaining retention of an increasing number of dislocation pile-ups and causing a significant increase in strength. Further increasing stress produces cracks primarily in the equiaxed second phase regions (Figs. 7 and 8) due to their lower yield strength compared with the $\beta$-Ti matrix. However, although cracks form in the as-fabricated 
alloy, the ductile $\beta$-Ti matrix can act as continuous networks that separate and restrict cracks to isolated small regions in the material, preventing shearing through the entire sample. With further increasing compressive stress, shear bands are generated in the matrix and are blocked by the $\mathrm{CoTi}_{2} /(\mathrm{Cu}, \mathrm{Ni}) \mathrm{Ti}_{2}$ phases (Fig. 8). The interaction and multiplication of shear bands are characteristics of strain-softening, leading to the increase in plasticity. The blocking effect further contributes to the strength and plasticity of the ultrafine grained composites. Under high enough stress, cracks would be formed in the matrix, fracturing the as-fabricated bulk alloys.

Based on the discussed fracture mechanism for the equiaxed composite alloy, the yield strength of this type of materials is primarily determined by the hardness and area fraction of the second phases. It was recognized that the fcc $(\mathrm{Cu}, \mathrm{Ni}) \mathrm{Ti}_{2}$ phase solid solution has lower hardness than the $\mathrm{CoTi}_{2}$ intermetallic compound phase. Hence, considering the same phase region size in the second phases, the alloys with precipitated $\mathrm{CoTi}_{2}$ phases exhibit higher yield strength of than the alloy $\mathrm{G}$ with precipitated $(\mathrm{Cu}, \mathrm{Ni}) \mathrm{Ti}_{2}$ phase (Fig. 5 and Table 2). In summary, the as-fabricated alloys exhibit an excellent combination of high strength and large plasticity due to its particular microstructure and fracture mechanism.

\subsection{Guideline of composition design and processing route for equiaxed Ti-based composites}

Compared with crystalline powder during spark plasma sintering, amorphous powder possesses significant advantages in obtaining ultrafine/nanosized grained and high-density titanium alloys with an equiaxed microstructure and excellent mechanical properties. However, not all the alloys fabricated by sintering and crystallizing amorphous powder exhibits extraordinary mechanical properties. For example, the alloy $\mathrm{H}$ having a complex microstructure, from which composition is a bulk metallic glass former by rapid solidification, exhibits a low ultimate strength of $800 \mathrm{MPa}$ and brittle fracture. Only those alloys with microstructure consisting of equiaxed second phases dispersed in a ductile $\beta$-Ti matrix possess high strength along with large plasticity. Therefore, the key of obtaining high-performance titanium alloys for the given process of sintering and crystallizing amorphous powder is to design an alloy composition of which crystallized amorphous 
powder can form an ultrafine/nanosized grained microstructure with the second phases dispersed in a ductile $\beta$-Ti matrix. Let's consider the current Ti-Nb-(M-N)-(Al) alloy system as an example to propose the guideline of alloy design for obtaining high-performance titanium alloys via the process of sintering and crystallizing amorphous powder. Firstly, elements $\mathrm{M}$ and $\mathrm{N}$ must be infinite solid solution elements in Ti or the values of the enthalpy of mixing of the $\mathrm{M}-\mathrm{N}$ pairs must be near 0 , such as $(\mathrm{M}, \mathrm{N})$ could be $(\mathrm{Cu}, \mathrm{Ni})$ or $(\mathrm{Fe}, \mathrm{Co})$ groups [36]. The precipitated phase is primarily controlled by the elements $\mathrm{M}$ and $\mathrm{N}$ in this system. Secondly, to obtain a composite microstructure of ultrafine grained precipitated phases surrounded by a continuous ductile $\beta$-Ti matrix, the content of $\beta$-Ti stabilizer elements in this system should be adequate. Thirdly, yield strength can be improved by adding a small amount of $\mathrm{Al}$, but the content of $\mathrm{Al}$ should be controlled to a reasonable level, at which the $\mathrm{Al}$ element cannot result in a new compound with other elements during mechanical alloying. Finally, a high-density random-packed structure of the as-milled amorphous powder is a favorable factor for forming nanostructured or ultrafine grains. It is also recognized that the as-fabricated alloys by sintering and crystallizing amorphous powder prefer to form nanosized/ultrafine equiaxed grained microstructure (Fig. 4). The SCed bulk alloys from amorphous powder also have better mechanical properties than the alloy consolidated from crystalline powders or blended element powders [6]. Hence, obtaining amorphous powder is a key procedure when fabricating high-performance titanium alloys. However, the alloys consolidated from amorphous powder whose composition has a high glass forming ability often display low strength and brittle facture (Fig. 5). Therefore, for the process route in this work, the glass forming ability of the designed composition must be sacrificed for fabricating a titanium alloy with excellent mechanical properties. Theoretically, the alloy composition with low glass forming ability may be difficult to amorphize by using gas atomization. Hence, mechanical alloying becomes the necessary and powerful route to form amorphous powder for the alloy composition with low glass forming ability.

In summary, amorphous powder with designed composition possesses excellent characteristics, such as viscous flow in its supercooled liquid region and a highly dense random-packed structure [8], which can be used to fabricate high-density alloy with ultrafine/nanosized equiaxed microstructure. However, alloys are typically composed of 
brittle intermetallic compounds after crystallizing from amorphous state. For the process of sintering and crystallizing amorphous powder studied in this work, alloy compositions are firstly designed to have potential of forming a microstructure of an equiaxed second phase dispersed in ductile $\beta$-Ti matrix. Although amorphous phase may be not able to form in the designed alloy by rapid solidification or gas atomization, it is sufficient if amorphous alloy powder could be synthesized by mechanical alloying [37]. Then, nanostructured or ultrafine grains can easily be achieved by accelerating the nucleation rate and suppressing the grain growth induced by increasing heating rate and decreasing sintering temperature during the sintering procedure.

\section{Conclusion}

A series of TiNb-based composites with different compositions were fabricated by sintering and crystallizing mechanically alloyed amorphous powder. Microstructural analysis indicate that, compared with the sintered $\mathrm{Ti}_{70} \mathrm{Nb}_{30}$ alloy with only a single $\beta$-Ti phase, the sintered and crystallized (SCed) Ti-Nb-Fe-Co and Ti-Nb-Fe-Co-Al alloys display a microstructure consisting of a precipitated equiaxed $\mathrm{CoTi}_{2}$ second phase in a $\beta$-Ti matrix. The grain size of the $\mathrm{CoTi}_{2}$ phase refines with increasing $\mathrm{Fe}$ content in $\mathrm{Ti}-\mathrm{Nb}-\mathrm{Fe}-\mathrm{Co}-\mathrm{Al}$ alloy system. For Ti-Nb-Cu-Ni-Al alloy system, the SCed alloys show a microstructure composed of ultrafine-grained and equiaxed $(\mathrm{Cu}, \mathrm{Ni}) \mathrm{Ti}_{2}$ second phase embedded in a $\beta$-Ti matrix; higher $\mathrm{Nb}$ content leads to the precipitation of $\mathrm{AlNbTi}_{2}$ phase. For the alloy $\mathrm{Ti}_{40.6} \mathrm{Zr}_{9.4} \mathrm{Cu}_{37.5} \mathrm{Ni}_{9.4} \mathrm{Al}_{3.1}$ with high glass forming ability, a complex microstructure with several intermetallic compounds forms in the SCed bulk alloy.

Mechanical property testing shows that, compared with high compressive plasticity for the sintered single $\beta$-Ti $\mathrm{Ti}_{70} \mathrm{Nb}_{30}$ alloy, the SCed Ti-Nb-Fe-Co-Al and Ti-Nb-Cu-Ni-Al composites exhibit an excellent combination of ultra-high yield and ultimate strength and ultra-large plasticity. The $\mathrm{SCed} \mathrm{Ti}_{40.6} \mathrm{Zr}_{9.4} \mathrm{Cu}_{37.5} \mathrm{Ni}_{9.4} \mathrm{Al}_{3.1}$ bulk alloy with a complex microstructure displays brittle fracture behavior. Fracture mechanism study implies that the ultrahigh strength is induced by the dislocation blocking effect by the precipitated ultrafine-grained and equiaxed second phases, while ultra-large plasticity results from the 
interaction and multiplication of generated shear bands in the ductile $\beta$-Ti matrix. The dependence of microstructure and mechanical properties proves that achieving a ductile $\beta$-Ti matrix is critical for the process investigated to form high-performance titanium alloys by sintering and crystallizing amorphous powder. It is expected that the results shown herein will shed light on some basic guidelines for the design and fabrication of high-performance titanium alloys.

\section{Acknowledgments}

This work was supported by the National Natural Science Foundation of China (No. 51574128), the Guangdong Natural Science Foundation for Research Team (No.2015A030312003), and the Guangdong Natural Science Foundation (No. S2013010012147).

\section{References:}

[1] C. Leyens, M. Peters, Titanium and titanium alloys: Fundamentals and Applications, Wiley-VCH, Weinheim, 2003.

[2] A. Inoue, A. Takeuchi, Acta. Mater. 59 (2011) 2243-2267.

[3] G. He, J. Eckert, W. Löser, L. Schultz, Nat. Mater. 2 (2003) 33-37.

[4] Z.Y. Zhang, Y. Wu, J. Zhou, H. Wang, X.J. Liu, Z.P. Lu, Scripta. Mater. 69 (2013) 73-76.

[5] I. Sen, S. Tamirisakandala, D.B. Miracle, U. Ramamurty. Acta. Mater. 55 (2007) 4983-4993.

[6] C. Yang, L.H. Liu, Q.R. Cheng, D.D. You, Y.Y. Li, Mater. Sci. Eng. A. 580 (2013) 397-405.

[7] L.H. Liu, C. Yang, F. Wang, S.G. Qu, X.Q. Li, W.W. Zhang, Y.Y. Li, L.C. Zhang, Mater. Design 79 ( 2015) 1-5.

[8] T. Yamasaki, S. Maeda, Y. Yokoyama, D. Okai, T. Fukami, H.M. Kimura, A. Inoue, Intermetallics 14 (2006) 1102-1106.

[9] L.H. Liu, C. Yang, Y.G. Yao, F. Wang, W.W. Zhang, Y. Long, Y.Y. Li, Intermetallics 66 (2015) 1-7.

[10] C. Yang, L.H. Liu, Y.G. Yao, Y.H. Li, Y.Y. Li, J. Alloy. Compd. 586 (2014) 542-548.

[11] D.Q. Zhao, M.X. Pan, W.H. Wang, B.C. Wei, T. Okada, W. Utsumi, J. Phys. Condens. Matter 15 (2003) L749-L753.

[12] U. Kühn, N. Mattern, A. Gebert, M. Kusy, M. Boström, U. Siegel, L. Schultz, J. Appl. Phys. 98 (2005) 054307.

[13] C. Suryanarayana, Prog. Mater. Sci. 46 (2001) 1-184.

[14] A. Helth, U. Siegel, U. Kühna, T. Gemminga, W. Gruner, S. Oswald, T. Mar, J. Freudenberger, J. Scharnweber, C.G. Oertel, W. Skrotzki, L. Schultz, J. Eckert, Acta. Mater. 61 (2013) 3324-3334.

[15] Y.Y. Li, C. Yang, W.P. Chen, X.Q. Li, J. Mater. Res. 23 (2008) 745-754.

[16] L.V. Louzguina-Luzgina, D.V. Louzguine-Luzgin, A. Inoue, Intermetallics 14 (2006) 255-259.

[17] D.V. Louzguine-Luzgin, L.V. Louzguina-Luzgina, H. Kato, A. Inoue. Acta. Mater. 53 (2005) 2009-2017. 
[18] Y.Y. Li, C. Yang, S.G. Qu, X.Q. Li, W.P. Chen, Mater. Sci. Eng. A 528 (2010) 486-493.

[19] L.V. Louzguina-Luzgina, D.V. Louzguine-Luzgin, A. Inoue, Phil. Mag. Lett. 84 (2004) 359-364.

[20] G. He, W. Löser, J. Eckert, Acta Mater. 51 (2003) 5223-5234.

[21] J.M. Park, J.H. Han, K.B. Kim, N. Mattern, J. Eckert, D.H. Kim, Phil. Mag. Lett. 89 (2009) 623-632.

[22] Y.J. Huang, J. Shen, J.F. Sun, X.B. Yu, J. Alloy. Compd. 427 (2007) 171-175.

[23] S.L. Zhu, X.M. Wang, A. Inoue, Intermetallics 16 (2008) 1031-1035.

[24] J. Cheney, H. Khalifa, K. Vecchio, Mater. Sci. Eng. A 506 (2009) 94-100.

[25] L.M. Zou, C. Yang, Y. Long, Z.Y. Xiao, Y.Y. Li, Powder. Metall. 55 (2012) 66-70.

[26] Y. Chen, C. Yang, L.M. Zou, S.G. Qu, X.Q. Li, Y.Y. Li, J. Non-Cryst. Solids 359 (2013) 15-20.

[27] G. He, J. Eckert, W. Löser, M. Hagiwara, Acta. Mater. 52 (2004) 3035-3046.

[28] L.C. Zhang, J. Das, H.B. Lu, C. Duhamel, M. Calin, J. Eckert, Scripta Mater. 57 (2007) 101-104.

[29] J. Das, F. Ettingshausen, J. Eckert, Scripta Mater. 58 (2008) 631-634.

[30] L.C. Zhang, H. Lu, C. Mickel, J. Eckert, Appl. Phys. Lett. 91 (2007) 051906.

[31] C. Yang, X.M. Wu, J. Zeng, Y.H. Li, S.G. Qu, W.P. Chen, Mater. Design 52 (2013) 655-662.

[32] Y.Y. Li, L.M. Zou, C. Yang, Y.H. Li, L.J. Li, Mater. Sci. Eng. A. 560 (2013) 857-861.

[33] W.P. Chen, X.M. Wu, C. Yang, X.Q. Li, M.D. Chen. Y.Y. Li, Mater. Trans. 53 (2012) 531-536.

[34] Y.Y. Li, C. Yang, W.P. Chen, X.Q. Li, S.G. Qu, J. Mater. Res. 24 (2009) 2118-2122.

[35] D. Tabor, The Hardness of Metals, Oxford University Press, New York, 1951.

[36] A. Takeuchi, A. Inoue, Mater. Trans. 46 (2005) 2817-2829.

[37] L.C. Zhang, Z.Q. Shen, J. Xu, Mater. Sci. Eng. A. 394 (2005) 204-209.

\section{Figure caption:}

Fig. 1 (a) XRD patterns of the as-milled alloy powder with different compositions for different milling time. (b) Variation of the lattice parameter of $\beta$-Ti phase in the alloy powder for different milling time. Alloy A: $\mathrm{Ti}_{70} \mathrm{Nb}_{30}$, alloy B: $\mathrm{Ti}_{65} \mathrm{Nb}_{22.5} \mathrm{Fe}_{6.25} \mathrm{Co}_{6.25}$, alloy $\mathrm{C}$ :

$\mathrm{Ti}_{66} \mathrm{Nb}_{13} \mathrm{Fe}_{8} \mathrm{Co}_{6.8} \mathrm{Al}_{6.2}$ and alloy $\mathrm{H}: \mathrm{Ti}_{40.6} \mathrm{Zr}_{9.4} \mathrm{Cu}_{37.5} \mathrm{Ni}_{9.4} \mathrm{Al}_{3.1}$.

Fig. 2 SEM micrographs of the 70h-milled alloy powder with different compositions: (a) alloy A, (b) alloy B, (c) alloy C, and (d) alloy H.

Fig. 3 XRD patterns of the sintered and crystallized bulk alloys. "S-X" indicates the alloy composition sintered at a specific sintering temperature, where " $S$ " represents the alloy composition and " $\mathrm{X}$ " denotes the sintering temperature. 
Fig. 4 SEM micrographs of the sintered and crystallized bulk alloys fabricated at different sintering temperatures: (a) A-900, (b) C-900, (c) E-900, (d) F-900, (e) G-900, and (f) $\mathrm{H}-800$. "S-X" indicates the alloy composition sintered at a specific sintering temperature, where "S" represents the alloy composition and " $\mathrm{X}$ " denotes the sintering temperature.

Fig. 5 (a) Compressive engineering stress-strain curves for the sintered and crystallized bulk alloys, A-F denote the alloys sintered at temperature of $1000{ }^{\circ} \mathrm{C}, \mathrm{H}$ denotes the alloy sintered at $800{ }^{\circ} \mathrm{C}$. (b) True stress-strain curves of the alloys A-1000 and C-1000. The inset in (b) shows the relationship of $\ln \sigma_{t}$ vs $\ln \varepsilon_{t}$, describing the work-hardening behavior. "S-X" indicates the alloy composition sintered at a specific sintering temperature, where " $\mathrm{S}$ " represents the alloy composition and " $\mathrm{X}$ " denotes the sintering temperature.

Fig. 6 TEM observations of the partly deformed sample B-1000 (strain at 20\%): (a) bright-field TEM image, (b) a SAED pattern of $\beta$-Ti matrix, (c) high-resolution TEM image of floc shown in the square area in (a), and the inset is the Fourier-transformed image for a square area in (c), and (d) inverse Fourier-transformed image for the square area in (c).

Fig. 7 TEM observations of partly deformed sample G-1000 at strain of 20\%: (a) bright-field TEM image, (b) dislocations blocked by the $(\mathrm{Cu}, \mathrm{Ni}) \mathrm{Ti}_{2}$ phase, (c) nanosized shear band at the grain boundary of $(\mathrm{Cu}, \mathrm{Ni}) \mathrm{Ti}_{2}$ phase and $\beta$-Ti phase, (d) high-resolution TEM image of $\mathrm{AlNbTi}_{2}$ phase, and the corresponding SAED patterns of (e) $\beta-\mathrm{Ti}$, (f) $(\mathrm{Cu}, \mathrm{Ni}) \mathrm{Ti}_{2}$ and (g) $\mathrm{AlNbTi}_{2}$ phases.

Fig. 8 SEM micrographs of the polished and fractured surfaces of bulk alloy samples: (a) A-1000, (b) B-1000, (c) C-1000, and (d) G-1000. "S-X" indicates the alloy composition sintered at a specific sintering temperature, where " $\mathrm{S}$ " represents the alloy composition and " $\mathrm{X}$ " denotes the sintering temperature.

Fig. 9 SEM fractures micrographs of the SCed bulk alloys: (a) B-950, (b) B-950, (c) F-900, and (d) G-900. "S-X" indicates the alloy composition sintered at a specific sintering temperature, where " $S$ " represents the alloy composition and " $\mathrm{X}$ " denotes the sintering temperature. 

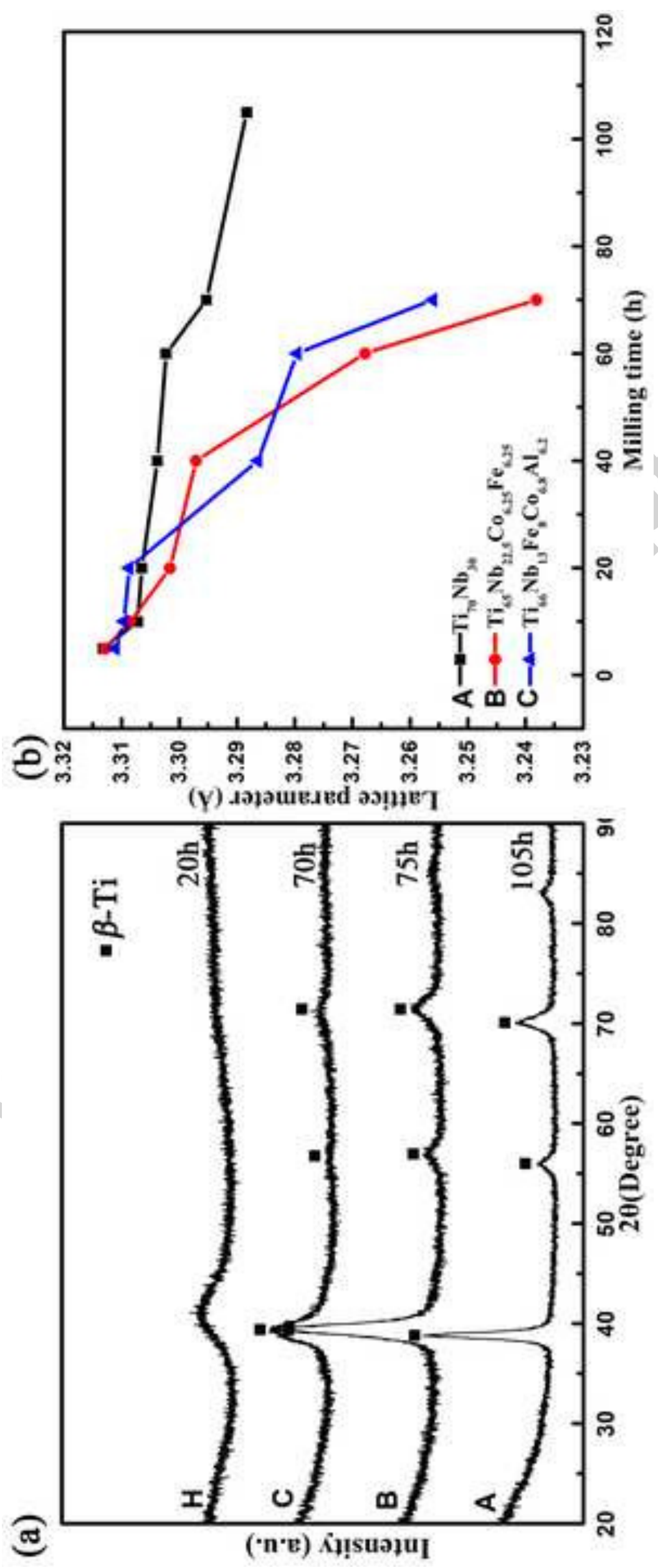

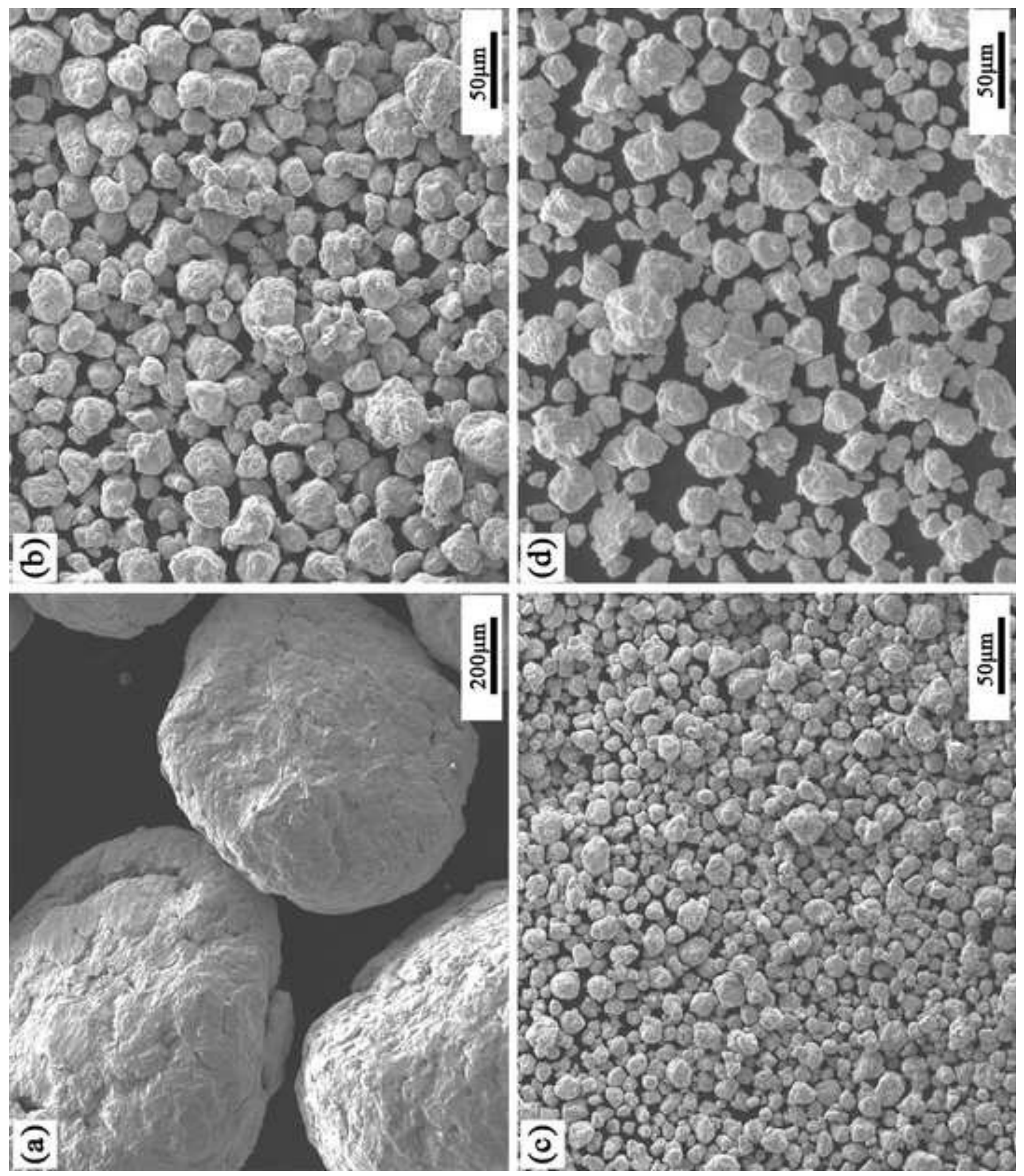

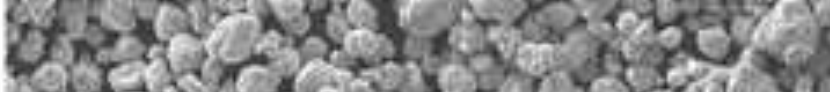

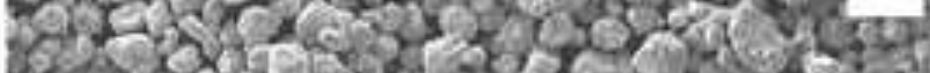

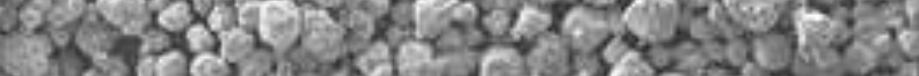

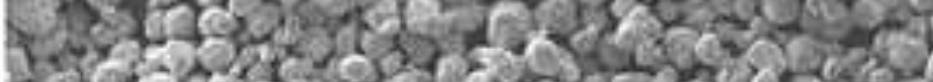

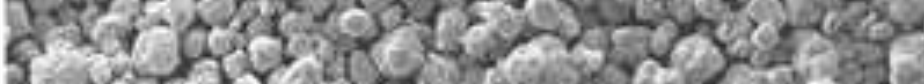

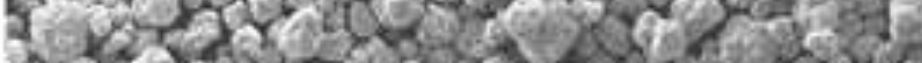
1. 2 a

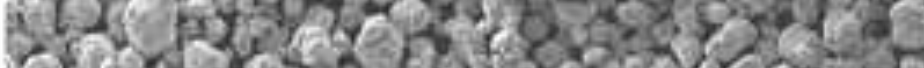

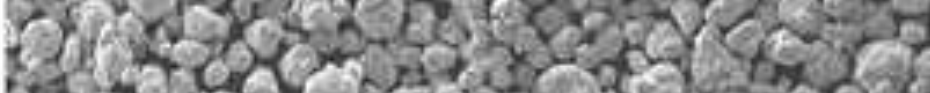

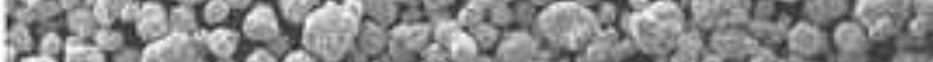

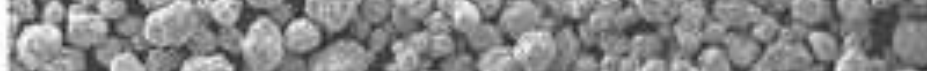

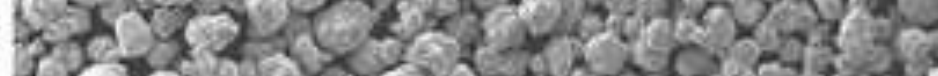

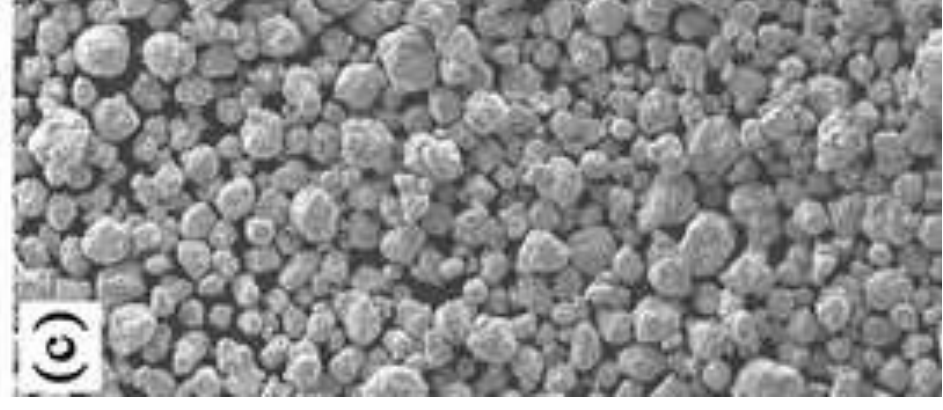




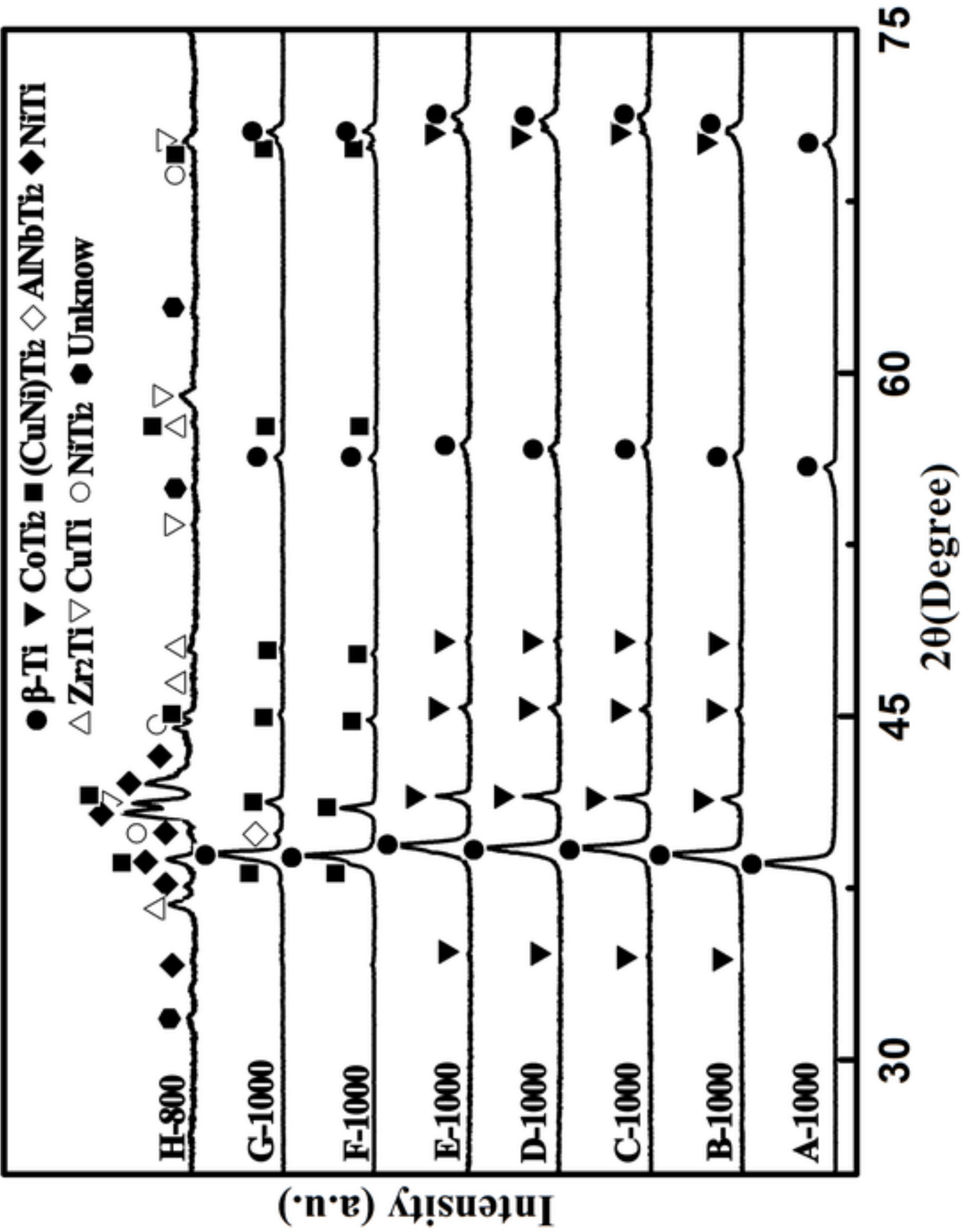


(a)

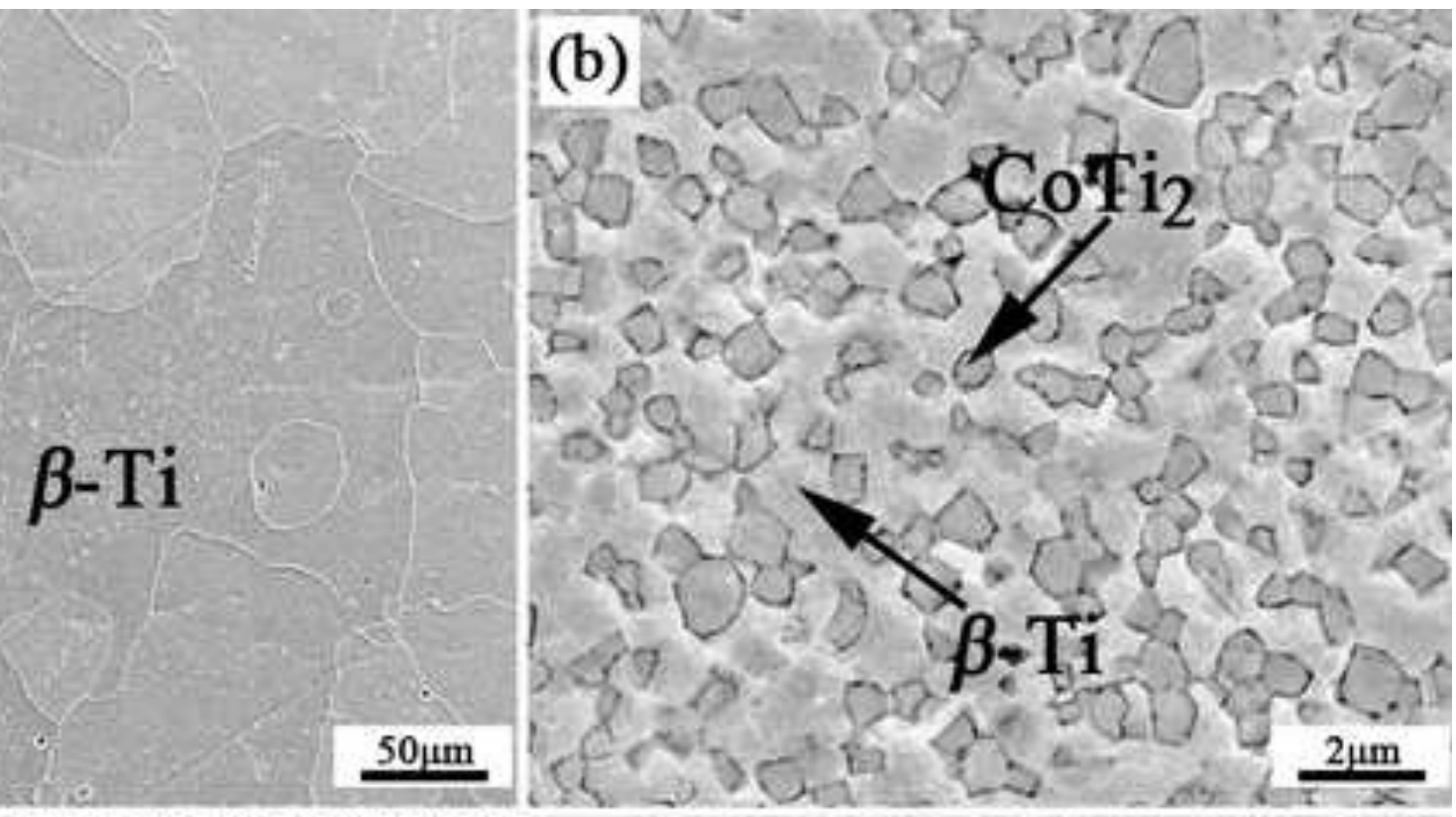

(c)

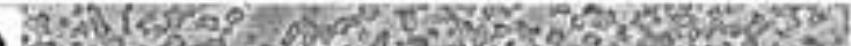

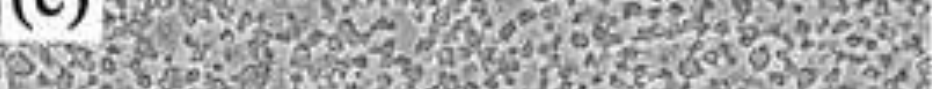

(d)

2.5.

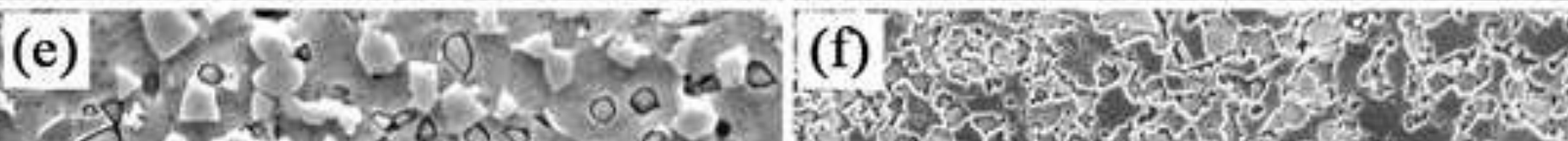

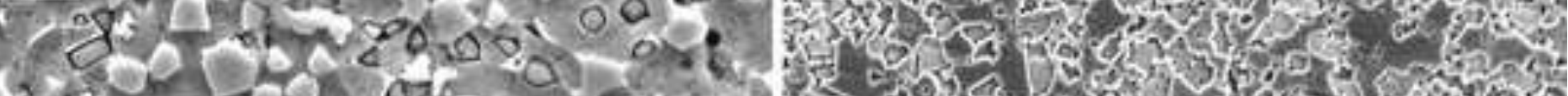

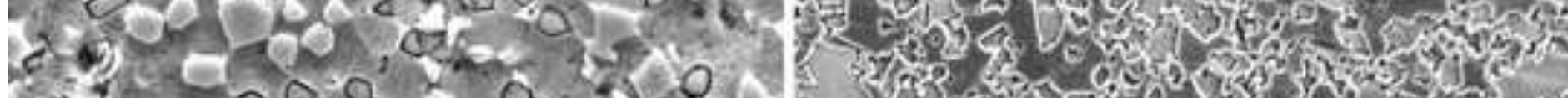

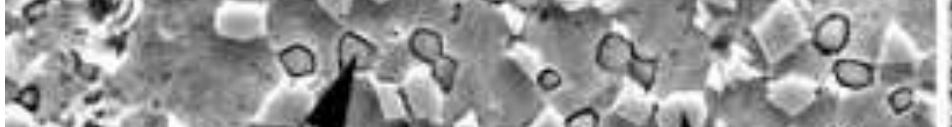
3.4.

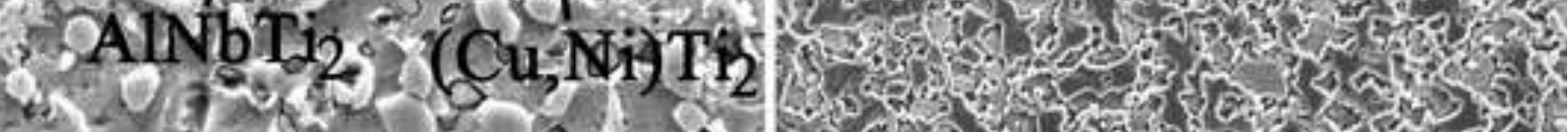

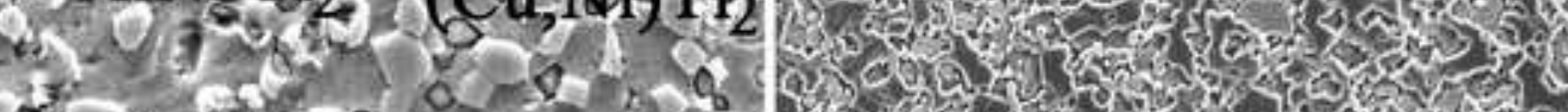

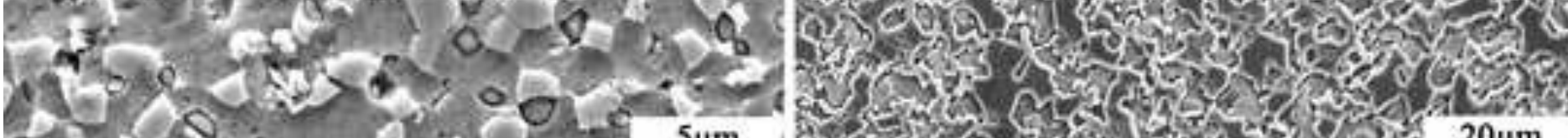

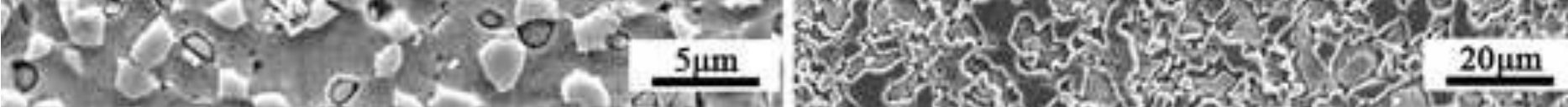



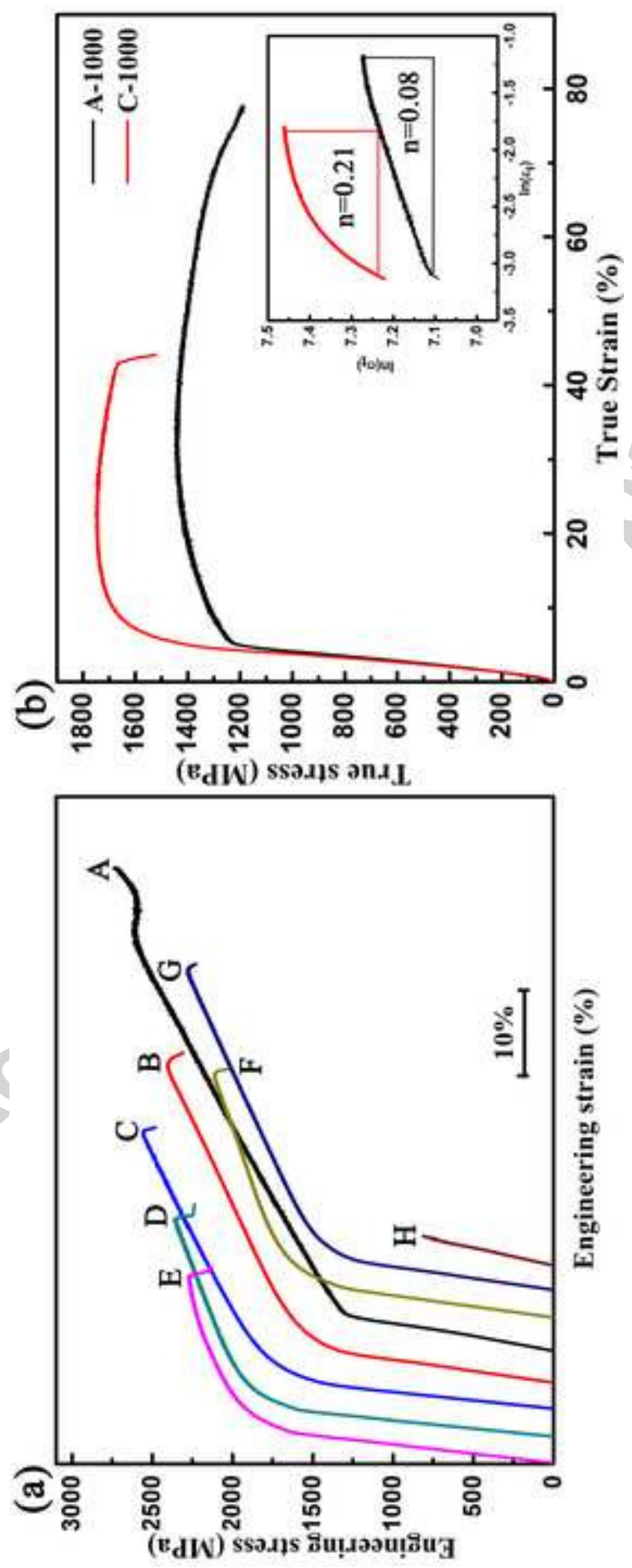

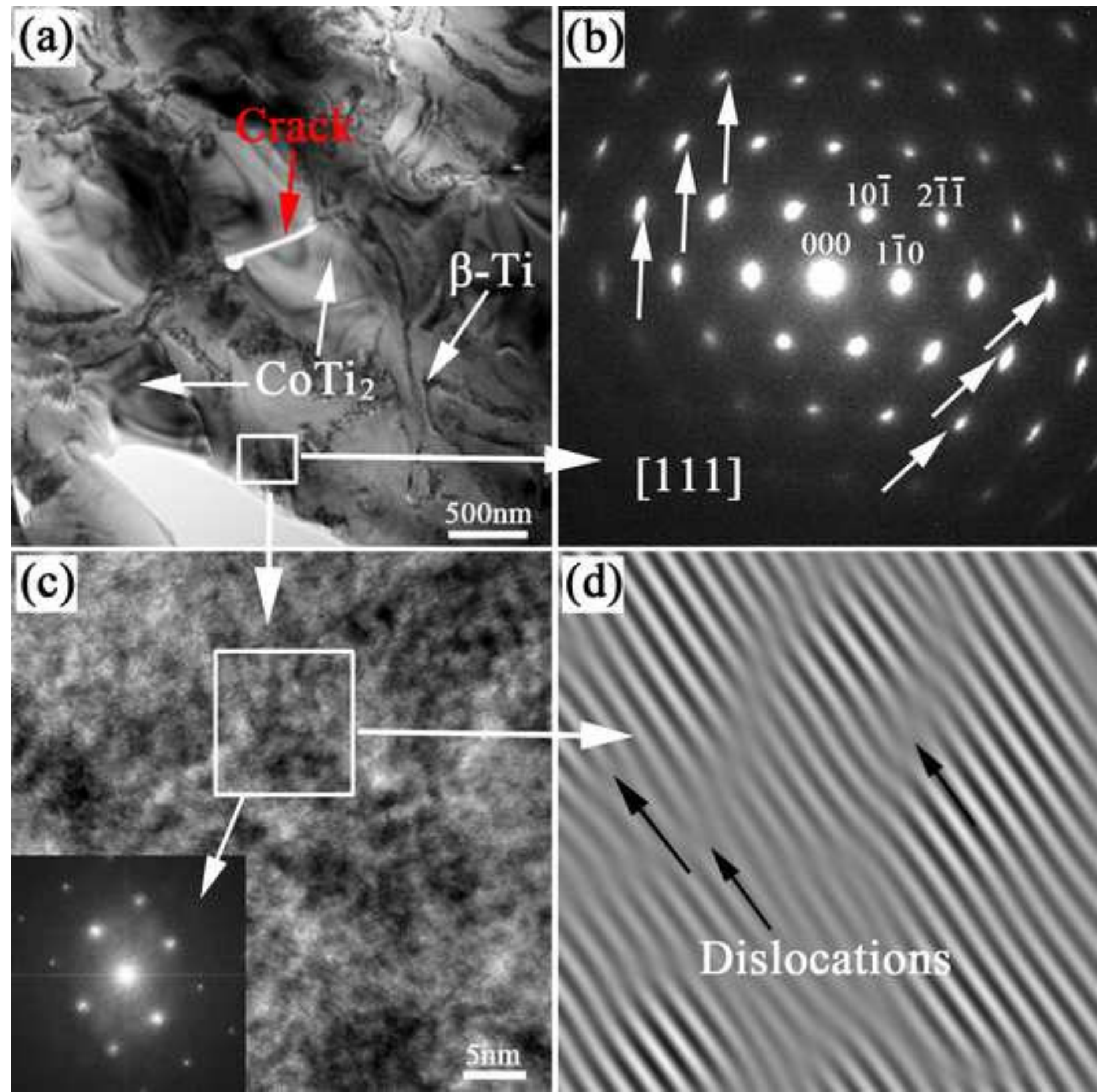

Dislocations
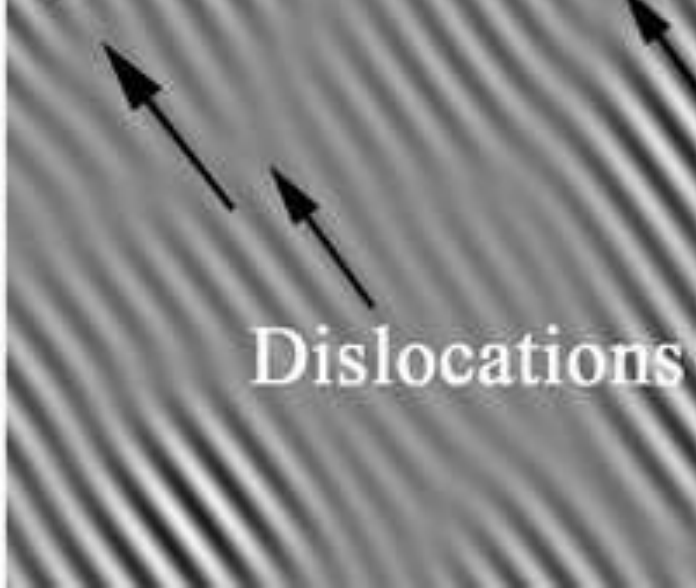

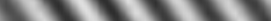




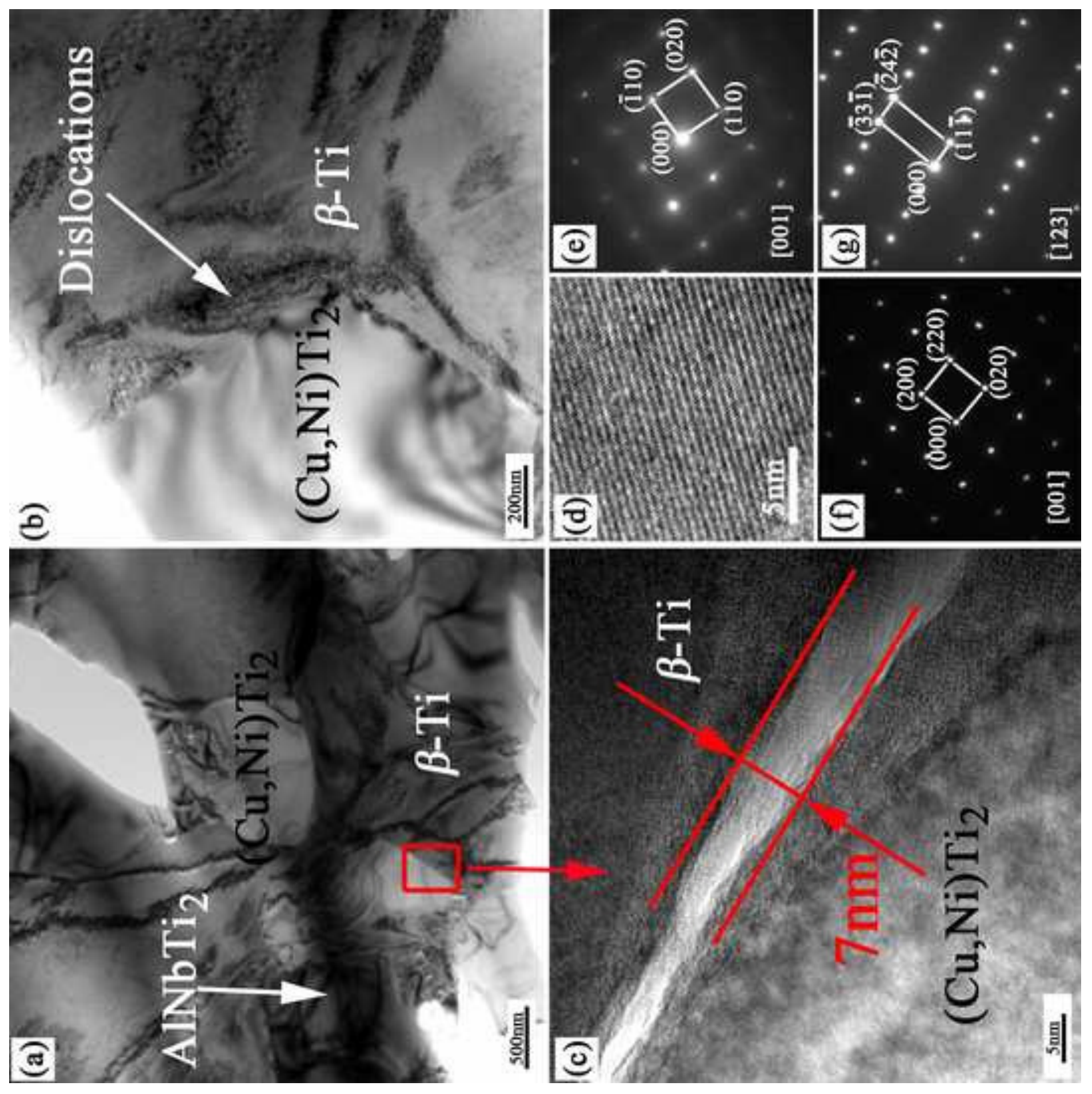




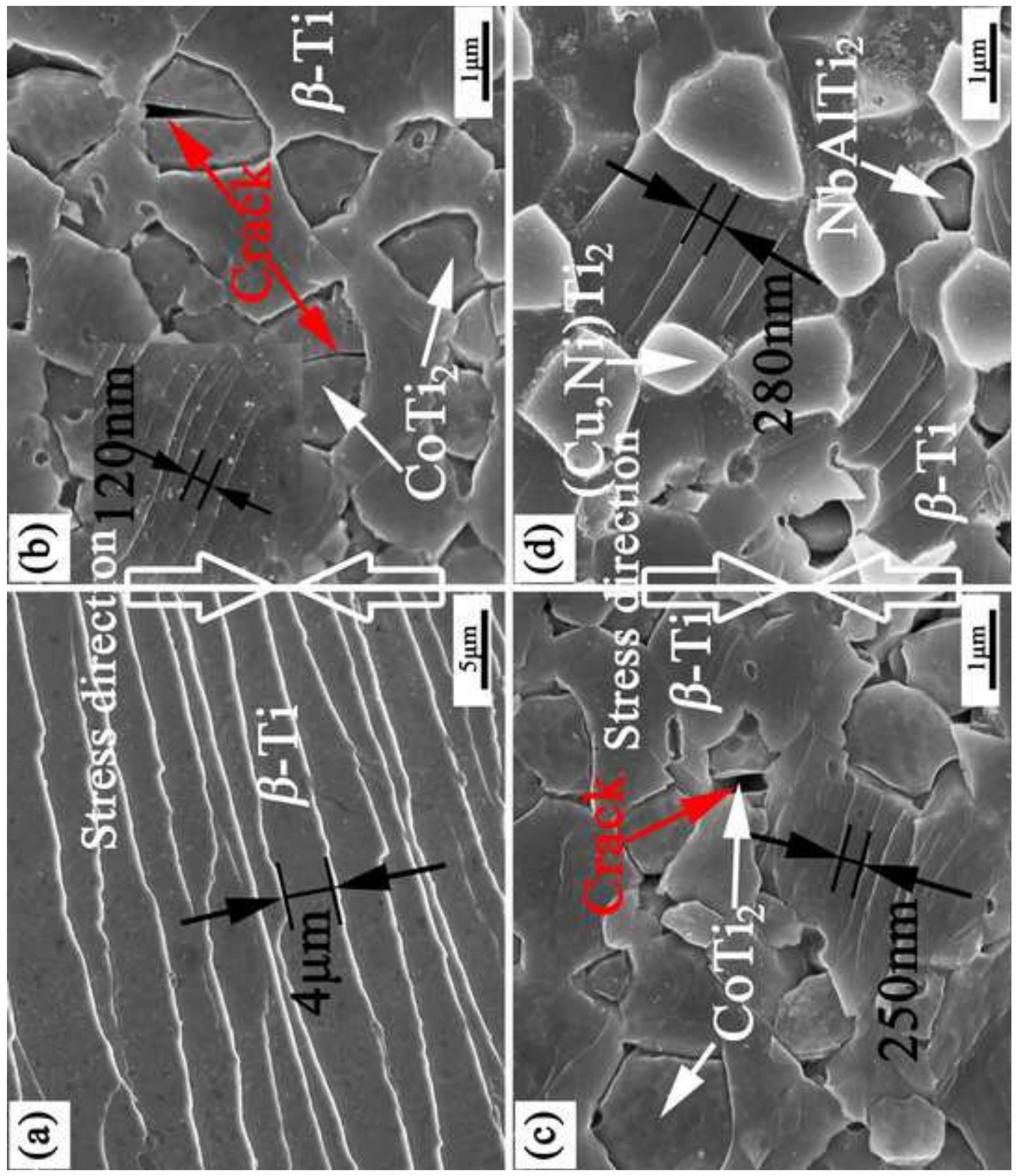



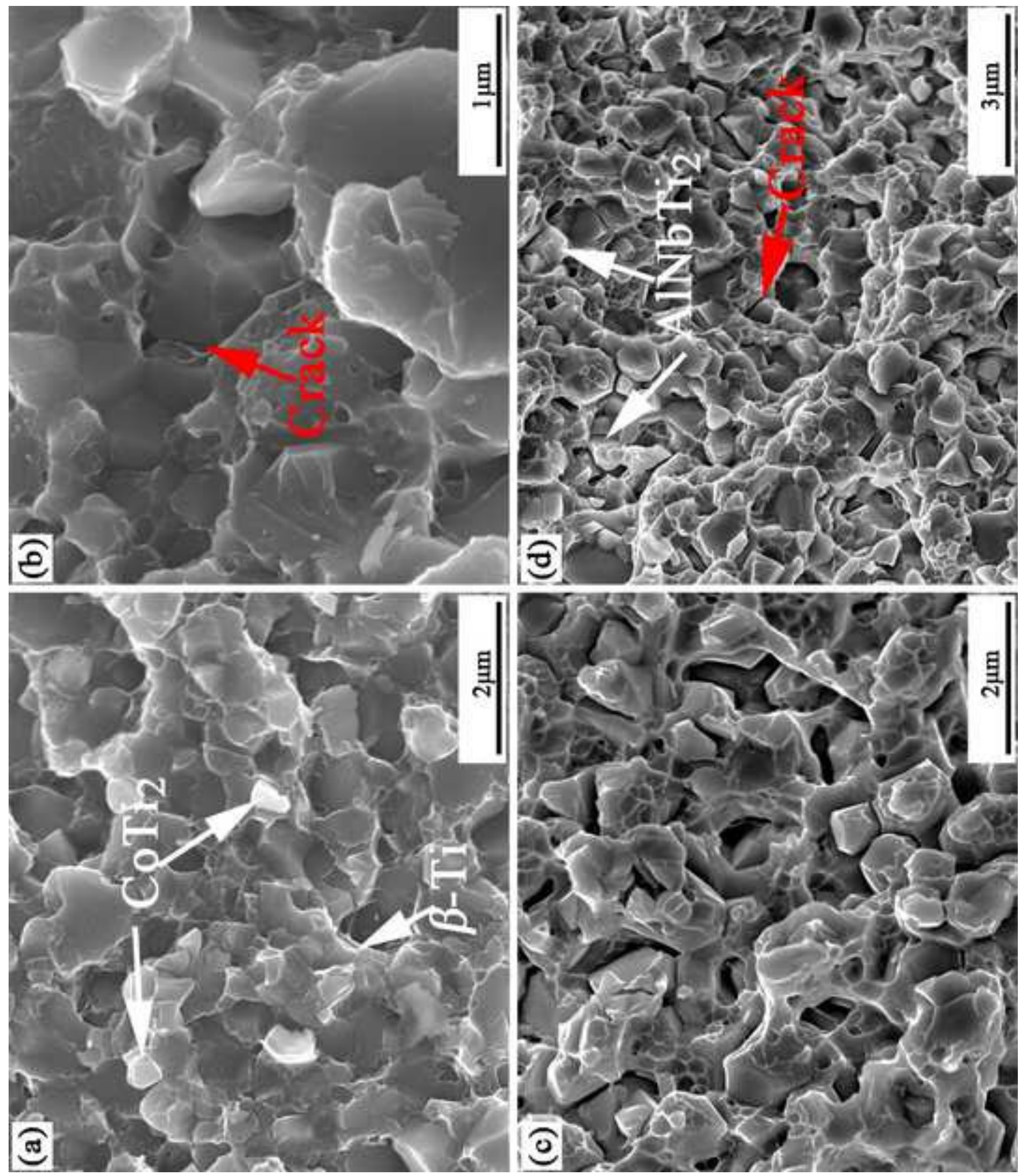